\title{
Holocene climate aridification trend and human impact interrupted by millennial- and centennial-scale climate fluctuations from a new sedimentary record from Padul (Sierra Nevada, southern Iberian Peninsula)
}

\author{
María J. Ramos-Román ${ }^{1}$, Gonzalo Jiménez-Moreno ${ }^{1}$, Jon Camuera ${ }^{1}$, Antonio García-Alix ${ }^{1}$, R. Scott Anderson ${ }^{2}$, \\ Francisco J. Jiménez-Espejo ${ }^{3}$, and José S. Carrión ${ }^{4}$ \\ ${ }^{1}$ Departamento de Estratigrafía y Paleontología, Universidad de Granada, Granada, Spain \\ ${ }^{2}$ School of Earth Sciences and Environmental Sustainability, Northern Arizona University, \\ Flagstaff, Arizona, USA \\ ${ }^{3}$ Department of Biogeochemistry, Japan Agency for Marine-Earth Science and \\ Technology (JAMSTEC), Yokosuka, Japan \\ ${ }^{4}$ Departamento de Biología Vegetal, Facultad de Biología, Universidad de Murcia, \\ Murcia, Spain
}

Correspondence: María J. Ramos-Román (mjrr@ugr.es)

Received: 21 August 2017 - Discussion started: 24 August 2017

Revised: 12 December 2017 - Accepted: 14 December 2017 - Published: 26 January 2018

\begin{abstract}
Holocene centennial-scale paleoenvironmental variability has been described in a multiproxy analysis (i.e., lithology, geochemistry, macrofossil, and microfossil analyses) of a paleoecological record from the Padul Basin in Sierra Nevada, southern Iberian Peninsula. This sequence covers a relevant time interval hitherto unreported in the studies of the Padul sedimentary sequence. The $\sim 4700$-year record has preserved proxies of climate variability, with vegetation, lake levels, and sedimentological change during the Holocene in one of the most unique and southernmost wetlands in Europe. The progressive middle and late Holocene trend toward arid conditions identified by numerous authors in the western Mediterranean region, mostly related to a decrease in summer insolation, is also documented in this record; here it is also superimposed by centennial-scale variability in humidity. In turn, this record shows centennialscale climate oscillations in temperature that correlate with well-known climatic events during the late Holocene in the western Mediterranean region, synchronous with variability in solar and atmospheric dynamics. The multiproxy Padul record first shows a transition from a relatively humid middle Holocene in the western Mediterranean region to more aridity from $\sim 4700$ to $\sim 2800$ cal yr BP. A rela-
\end{abstract}

tively warm and humid period occurred between $\sim 2600$ and $\sim 1600$ calyr BP, coinciding with persistent negative North Atlantic Oscillation (NAO) conditions and the historic Iberian-Roman Humid Period. Enhanced arid conditions, co-occurring with overall positive NAO conditions and increasing solar activity, are observed between $\sim 1550$ and $\sim 450$ cal yr BP $(\sim 400$ to $\sim 1400 \mathrm{CE})$ and colder and warmer conditions occurred during the Dark Ages and Medieval Climate Anomaly (MCA), respectively. Slightly wetter conditions took place during the end of the MCA and the first part of the Little Ice Age, which could be related to a change towards negative NAO conditions and minima in solar activity. Time series analysis performed from local (Botryococcus and total organic carbon) and regional (Mediterranean forest) signals helped us determining the relationship between southern Iberian climate evolution, atmospheric and oceanic dynamics, and solar activity. Our multiproxy record shows little evidence of human impact in the area until $\sim 1550$ cal yr BP, when evidence of agriculture and livestock grazing occurs. Therefore, climate is the main forcing mechanism controlling environmental change in the area until relatively recently. 


\section{Introduction}

The Mediterranean area is situated in a sensitive region between temperate and subtropical climates, making it an important place to study the connections between atmospheric and oceanic dynamics and environmental change. Climate in the western Mediterranean and the southern Iberian Peninsula is influenced by several atmospheric and oceanic dynamics (Alpert et al., 2006), including the North Atlantic Oscillation (NAO) one of the principal atmospheric phenomena controlling climate in the area (Hurrell, 1995; Moreno et al., 2005). Recent NAO reconstructions in the western Mediterranean relate negative and positive NAO conditions with an increase and decrease, respectively, in winter (effective) precipitation (Trouet et al., 2009; Olsen et al., 2012). Numerous paleoenvironmental studies in the western Mediterranean have detected a link on millennial and centennial scales between the oscillations of paleoclimate proxies from sedimentary records with solar variability and atmospheric (i.e., NAO) and/or ocean dynamics during the Holocene (Moreno et al., 2012; Fletcher et al., 2013; Rodrigo-Gámiz et al., 2014). Very few montane and low-altitude lake records in southern Iberia document centennial-scale climate change (see, for example Zoñar Lake, Martín-Puertas et al., 2008), with most terrestrial records in the western Mediterranean region evidencing only millennial-scale cyclical changes. Therefore, higher-resolution decadal-scale analyses are necessary to analyze the link between solar activity and atmospheric and oceanographic systems with terrestrial environment in this area on shorter (i.e., centennial) timescales.

Sediments from lakes, peat bogs, and marine records from the western Mediterranean have documented an aridification trend during the late Holocene (Jalut et al., 2009; Carrión et al., 2010; Gil-Romera et al., 2010). This trend, however, was superimposed by shorter-term climate variability, as shown by several recent studies from the region (Carrión, 2002; Martín-Puertas et al., 2008; Fletcher et al., 2013; JiménezMoreno et al., 2013; Ramos-Román et al., 2016). This relationship between climate variability, culture evolution, and human impact during the late Holocene has also been the subject of recent paleoenvironmental studies (Magny, 2004; Carrión et al., 2007; López-Sáez et al., 2014; Lillios et al., 2016). However, it is still unclear whether climate or human activities have been the main force driving environmental change (i.e., deforestation) in this area during this time.

Within the western Mediterranean, the Sierra Nevada is the highest and southernmost mountain range on the Iberian Peninsula and thus presents a critical area for paleoenvironmental studies. Most high-resolution studies there come from high-elevation sites. The well-known Padul wetland site is located at the western foot of the Sierra Nevada (Fig. 1) and bears one of the longest continental records in southern Europe, with a sedimentary sequence of $\sim 100 \mathrm{~m}$ thick that could represent the last $1 \mathrm{Myr}$ (Ortiz et al., 2004). Several research studies, including radiocarbon dating and geo- chemistry and pollen analyses, have been carried out on previous cores from Padul and have documented glacialinterglacial cycles during the Pleistocene and up until the middle Holocene. However, the late Holocene section of the Padul sedimentary sequence has never been effectively retrieved and studied (Florschütz et al., 1971; Pons and Reille, 1988; Ortiz et al., 2004). This is due to the location of these previous corings within a current peat mine operation, where the upper (and nonproductive) part of the sedimentary sequence was missing.

Here we present a new record from the Padul Basin: Padul$15-05$, a $42.64 \mathrm{~m}$ long sediment core that, for the first time, contains a continuous record of the late Holocene (Fig. 2). A high-resolution multiproxy analysis of the upper $1.15 \mathrm{~m}$, the past $\sim 4700$ cal yr BP, has allowed us to determine a complete paleoenvironmental and paleoclimatic record on centennial and millennial scales. To accomplish this, we reconstructed changes in the Padul vegetation, sedimentation, climate, and human impact during the Holocene throughout the interpretation of the lithology, palynology, and geochemistry.

Specifically, the main objective of this paper is to determine environmental variability and climate evolution on the southern Iberian Peninsula and the western Mediterranean region and their linkages to Northern Hemisphere climate and solar variability during the latter Holocene. In order to do this, we compared our results with other paleoclimate records from the region and solar activity from the Northern Hemisphere for the past $\sim 4700$ cal yr BP (Bond et al., 2001; Laskar et al., 2004; Steinhilber et al., 2009; Sicre et al., 2016).

\section{Regional setting: Padul, climate, and vegetation}

Padul is located at the foothills of the Sierra Nevada, which is a W-E aligned mountain range located in Andalucía (southern Spain; Fig. 1). Climate in this area is Mediterranean, with cool and humid winters and hot and warm summer drought. The Sierra Nevada is strongly influenced by thermal and precipitation variations due to the altitudinal gradient (from $\sim 700$ to more than $3400 \mathrm{~m}$ ), which controls plant taxa distribution in different bioclimatic vegetation belts due to the variability in thermotypes and ombrotypes (Valle Tendero, 2004). According to the climatophilous series classification, the Sierra Nevada is divided into four different vegetation belts (Fig. 1). The cryo-oromediterranean vegetation belt, occurring above $\sim 2800 \mathrm{~m}$, is characterized by tundra vegetation and principally composed of species of Poaceae, Asteraceae, Brassicaceae, Gentianaceae, Scrophulariaceae, and Plantaginaceae between other herbs, with a number of endemic plants (e.g., Erigeron frigidus, Saxifraga nevadensis, Viola crassiuscula, Plantago nivalis). The oromediterranean belt, between $\sim 1900$ and $\sim 2800 \mathrm{~m}$, is principally made up of Pinus sylvestris, P. nigra, and Juniperus spp. and other shrubs such as species of Fabaceae, Cis- 
(a)

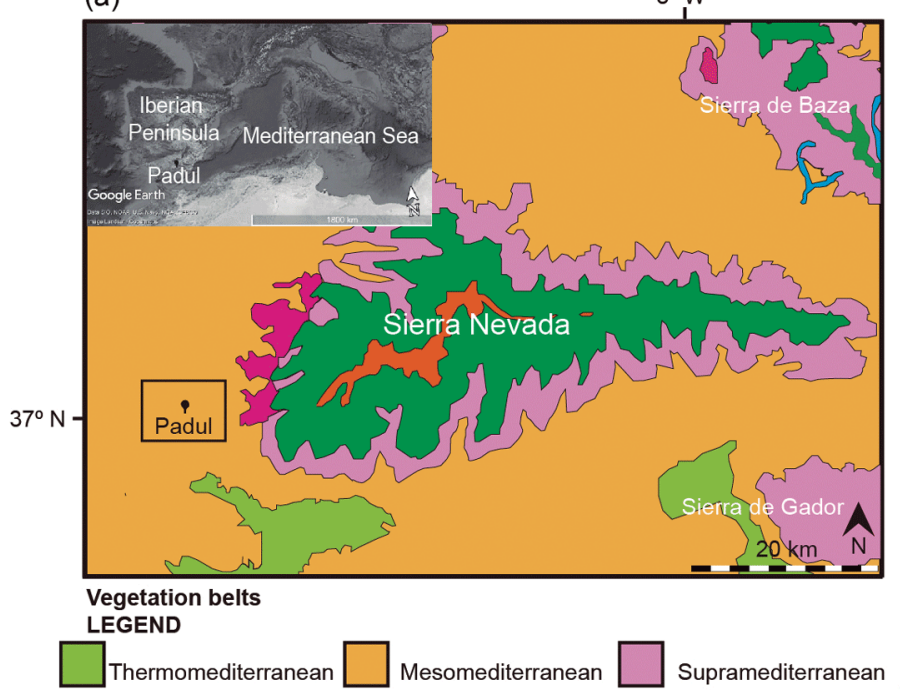

(b)

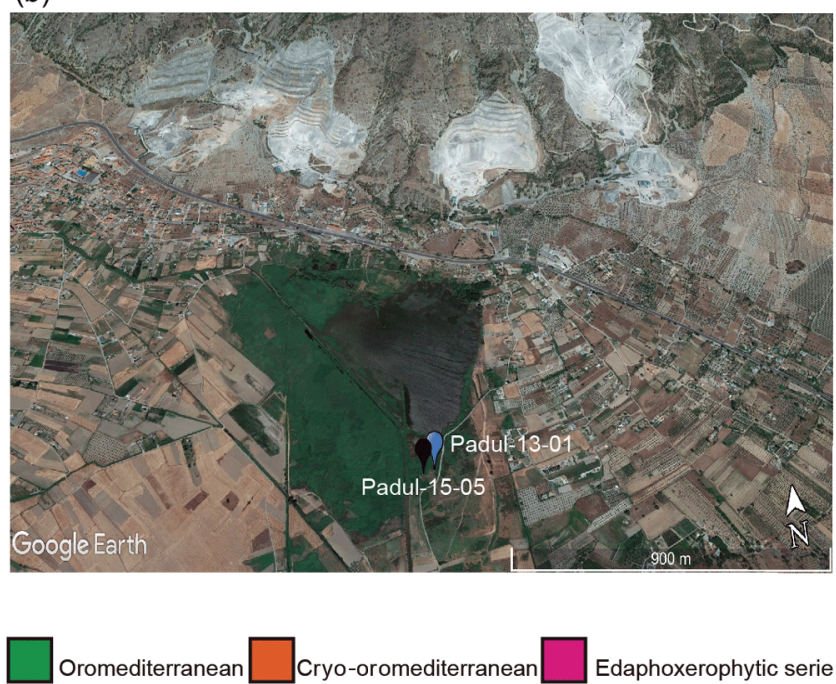

Figure 1. Location of Padul in the Sierra Nevada, southern Iberian Peninsula. Panel (a) is the map of the vegetation belts in the Sierra Nevada (Modified from REDIAM. Map of the vegetation series of Andalucía: http://laboratoriorediam.cica.es/VisorGenerico/?tipo=WMS). The inset map is the Google Earth image of the Iberian Peninsula in the Mediterranean region. Panel (b) is the Google Earth image (http: //www.google.com/earth/index.html) of the Padul wetland area showing the coring locations.

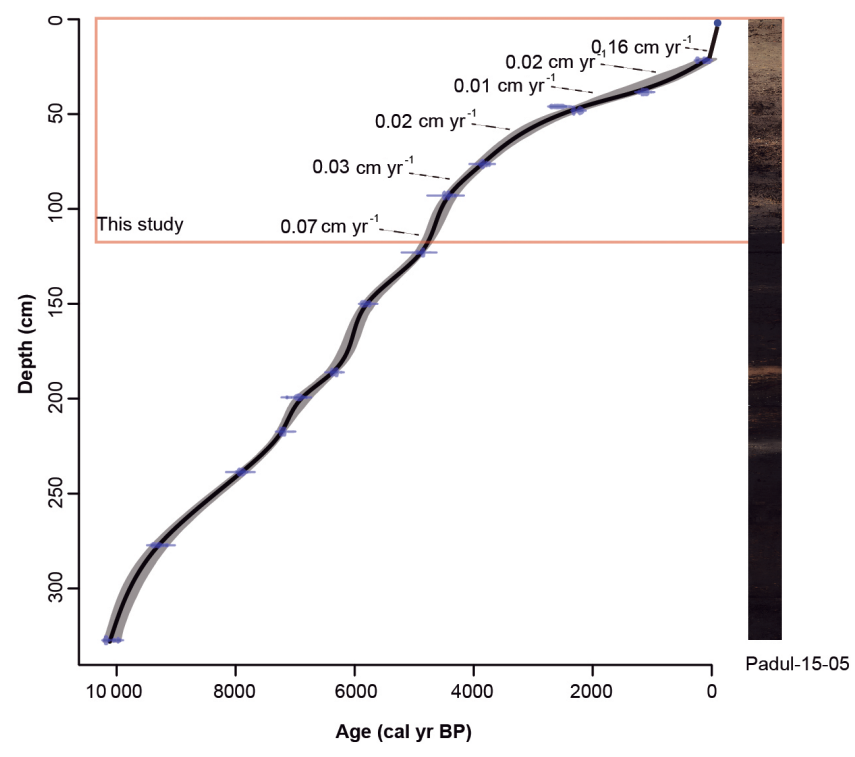

Figure 2. Photo of the Padul-15-05 sediment core with the agedepth model showing the part of the record that was studied here (red rectangle). The sediment accumulation rates (SARs) between individual segments are marked. See the body of the text for the explanation of the age reconstructions.

taceae, and Brassicaceae. The supramediterranean belt, from $\sim 1400$ to 1900 m a.s.l., bears principally Quercus pyrenaica, Q. faginea, Q. rotundifolia, and Acer opalus ssp. granatense with other trees and shrubs, including members of Fabaceae, Thymelaeaceae, and Cistaceae and Artemisia sp. being the most important. The mesomediterranean vegetation belt oc- curs between $\sim 600$ and $1400 \mathrm{~m}$ a.s.l. and is principally characterized by Quercus rotundifolia; some shrubs, herbs, and plants such as Juniperus sp.; and some species of Fabaceae, Cistaceae, and Liliaceae, among others (El Aallali et al., 1998; Valle, 2003). The human impact over this area, especially important during the last millennium, affected the natural vegetation distribution through fire, deforestation, cultivation (i.e., Olea), and subsequent reforestation (mostly $\mathrm{Pi}$ nus) (Anderson et al., 2011). The Padul Basin is situated in the mesomediterranean vegetation belt at approximately $725 \mathrm{~m}$ a.s.l. in the southeastern part of the Granada Basin. In this area and in addition to the characteristic vegetation at this elevation, nitrophilous communities occur in soils disrupted by livestock, pathways, or open forest and are normally related to anthropization (Valle, 2003).

This is one of the most seismically active areas in the southern Iberian Peninsula with numerous faults in the NWSE direction, with the Padul fault being one of these active normal faults (Alfaro et al., 2001). It is a small extensional basin approximately $12 \mathrm{~km}$ long and covering an area of approximately $45 \mathrm{~km}^{2}$, which is bounded by the Padul normal fault. The sedimentary infilling of the basin consists of Neogene and Quaternary deposits; upper Miocene conglomerates, calcarenites, and marls; and Pliocene and Quaternary alluvial sediments, lacustrine, and peat bog deposits (Domingo-García et al., 1983; Sanz de Galdeano et al., 1998; Delgado et al., 2002).

The Padul wetland is endorheic, with a surface of approximately $4 \mathrm{~km}^{2}$ placed in the Padul Basin that contains a sedimentary sequence characterized mostly by peat accumulation. The basin fill is asymmetric, with thicker sedimentary 
and peat infill to the northeast $(\sim 100 \mathrm{~m}$ thick; Florschütz et al., 1971; Domingo-García et al., 1983; Nestares and Torres, 1997) and progressively becoming thinner to the southwest (Alfaro et al., 2001). The main source area of allochthonous sediments in the bog is the Sierra Nevada, which is characterized at higher elevations by Paleozoic siliceous metamorphic rocks (mostly mica schists and quartzites) from the Nevado-Filabride complex and, at lower elevations and acting as bedrock, by Triassic dolomites, limestones, and phyllites from the Alpujárride Complex (Sanz de Galdeano et al., 1998). Geochemistry in the Padul sediments is influenced by detritic materials also primarily from the Sierra Nevada (Ortiz et al., 2004). Groundwater inputs into the Padul Basin come from the Triassic carbonate aquifers $(\mathrm{N}$ and $\mathrm{S}$ edge to the basin), the outflow of the Granada Basin (W edge to the basin), and the conglomerate aquifer to the east edge (Castillo Martín et al., 1984; Ortiz et al., 2004). The main water output is by evaporation and evapotranspiration, water wells, and canals (madres) that drain the water to the Dúrcal River to the southeast (Castillo Martín et al., 1984). Climate in the Padul area is characterized by a mean annual temperature of $14.4^{\circ} \mathrm{C}$ and a mean annual precipitation of $445 \mathrm{~mm}$ (http://www.aemet.es/).

The Padul-15-05 drilling site was located $\sim 50 \mathrm{~m}$ south of the present-day Padul lakeshore area. This basin area is presently subjected to seasonal water level fluctuations and is principally dominated by Phragmites australis (Poaceae). The lake environment is dominated by aquatic and wetland communities with Chara vulgaris, Myriophyllum spicatum, Potamogeton pectinatus, Potamogeton coloratus, Phragmites australis, Typha domingensis, Apium nodiflorum, Juncus subnodulosus, J. bufonius, Carex hispida, and Ranunculus muricatus, among others (Pérez Raya and López Nieto, 1991). Some sparse riparian trees occur along the northern lakeshore, such as Populus alba, Populus nigra, Salix sp., Ulmus minor, and Tamarix. At present Phragmites australis is the most abundant plant bordering the lake. Surrounding this area are cultivated crops with cereals, such as Triticum spp., as well as Prunus dulcis and Olea europea.

\section{Material and methods}

Two sediment cores, Padul-13-01 $\left(37^{\circ} 00^{\prime} 40^{\prime \prime} \mathrm{N}\right.$, $\left.3^{\circ} 36^{\prime} 134^{\prime \prime} \mathrm{W}\right)$ and Padul-15-05 $\left(37^{\circ} 00^{\prime} 39.77^{\prime \prime} \mathrm{N}\right.$, $\left.3^{\circ} 36^{\prime} 14.06^{\prime \prime} \mathrm{W}\right)$ with lengths of $58.7 \mathrm{~cm}$ and $42.64 \mathrm{~m}$, respectively, were collected between 2013 and 2015 from the wetland (Fig. 1). The cores were taken using a Rolatec RL-48-L drilling machine equipped with a hydraulic piston corer from the Scientific Instrumentation Centre of the University of Granada (UGR). The sediment cores were wrapped in film, put in core boxes, transported to UGR, and stored in a dark cool room at $4{ }^{\circ} \mathrm{C}$.

\subsection{Age-depth model (AMS radiocarbon dating)}

The core chronology was constrained using 14 accelerator mass spectrometry (AMS) radiocarbon dates from plant remains and organic bulk samples taken from the cores (Table 1). In addition, one sample with gastropods was also submitted for AMS radiocarbon analysis, although it was rejected due to important reservoir effects, which provided a very old date. Of these samples, 13 came from Padul-15-05 with one from the nearby Padul-13-01 (Table 1). We were able to use this date from the Padul-13-01 core as there is a very significant correlation between the upper parts of the Padul-15-05 and Padul-13-01 cores, shown by identical lithological and geochemical changes (Supplement S1; Fig. S1). The age model for the upper $\sim 3 \mathrm{~m}$ minus the upper $21 \mathrm{~cm}$ from the surface was built using the R code package "clam 2.2" (Blaauw, 2010) employing the calibration curve IntelCal 13 (Reimer et al., 2013), a $95 \%$ confidence range, a smooth spline (type 4) with a 0.20 smoothing value, and 1000 iterations (Fig. 2). The chronology of the uppermost $21 \mathrm{~cm}$ of the record was built using a linear interpolation between the last radiocarbon date and the top of the record (present, 2015 CE). Even though the length of the Padul-15-05 core is $\sim 43 \mathrm{~m}$, the studied interval in the work presented here is the uppermost $115 \mathrm{~cm}$ of the record, which is constrained by seven AMS radiocarbon dates (Fig. 2).

\subsection{Lithology, MS, XRF, and TOC}

The Padul-15-05 core was split longitudinally and was described in the laboratory with respect to lithology and color (Fig. 3). Magnetic susceptibility (MS) was measured with a Bartington MS3 operating with a MS2E sensor. MS measurements (in SI units) were obtained directly from the core surface every $0.5 \mathrm{~cm}$ (Fig. 3).

Elemental geochemical composition was measured with an X-ray fluorescence (XRF) Avaatech Core Scanner ${ }^{\circledR}$ at the University of Barcelona (Spain). A total of 33 chemical elements were measured with the XRF core scanner at $10 \mathrm{~mm}$ spatial resolution, using a $10 \mathrm{~s}$ count time, $10 \mathrm{kV}$ X-ray voltage, and X-ray current of $650 \mu \mathrm{A}$ for lighter elements and a $35 \mathrm{~s}$ count time, $30 \mathrm{kV} \mathrm{X}$-ray voltage, and X-ray current of $1700 \mu \mathrm{A}$ for heavier elements. There were 33 chemical elements measured but only the most representative with a major number of counts were considered ( $\mathrm{Si}, \mathrm{K}, \mathrm{Ca}, \mathrm{Ti}, \mathrm{Fe}, \mathrm{Zr}$, $\mathrm{Br}$, and $\mathrm{Sr}$ ). Results for each element are expressed as intensities in counts per second (cps) and normalized (norm.) for the total sum in counts per second in every measure (Fig. 3).

Total organic carbon (TOC) was analyzed every 2 or $3 \mathrm{~cm}$ throughout the core. Samples were previously decalcified with $1: 1 \mathrm{HCl}$ in order to eliminate the carbonate fraction. The percentage of organic carbon (OC \%) was measured with a Thermo Scientific Flash 2000 elemental analyzer from the Scientific Instrumentation Centre of the UGR (Spain). Percentage of TOC per gram of sediment was calculated from 
Table 1. Age data for the Padul-15-05 record. All ages were calibrated using R code package "clam 2.2" employing the calibration curve IntelCal 13 (Reimer et al., 2013) at the $95 \%$ confidence range.

\begin{tabular}{|c|c|c|c|c|c|c|}
\hline $\begin{array}{l}\text { Laboratory } \\
\text { number }\end{array}$ & Core & Material & $\begin{array}{r}\text { Depth } \\
(\mathrm{cm})\end{array}$ & $\begin{array}{r}\text { Age }\left({ }^{14} \mathrm{C} \text { yr }\right. \\
\mathrm{BP} \pm 1 \sigma)\end{array}$ & $\begin{array}{r}\text { Calibrated age } \\
\text { (cal yr BP) } 95 \% \\
\text { confidence interval }\end{array}$ & $\begin{array}{r}\text { Median age } \\
(\text { cal yr BP) }\end{array}$ \\
\hline Reference ages & & & 0 & $2015 \mathrm{CE}$ & -65 & -65 \\
\hline D-AMS 008531 & Padul-13-01 & Plant remains & 21.67 & $103 \pm 24$ & $23-264$ & 127 \\
\hline Poz-77568 & Padul-15-05 & Org. bulk sed. & 38.46 & $1205 \pm 30$ & $1014-1239$ & 1130 \\
\hline BETA-437233 & Padul-15-05 & Plant remains & 46.04 & $2480 \pm 30$ & $2385-2722$ & 2577 \\
\hline Poz-77569 & Padul-15-05 & Org. bulk sed. & 48.21 & $2255 \pm 30$ & $2158-2344$ & 2251 \\
\hline BETA-415830 & Padul-15-05 & Shell & 71.36 & $3910 \pm 30$ & $4248-4421$ & 4343 \\
\hline BETA- 437234 & Padul-15-05 & Plant remains & 76.34 & $3550 \pm 30$ & $3722-3956$ & 3838 \\
\hline BETA-415831 & Padul-15-05 & Org. bulk sed. & 92.94 & $3960 \pm 30$ & $4297-4519$ & 4431 \\
\hline Poz-74344 & Padul-15-05 & Plant remains & 122.96 & $4295 \pm 35$ & $4827-4959$ & 4871 \\
\hline BETA-415832 & Padul-15-05 & Plant remains & 150.04 & $5050 \pm 30$ & $5728-5900$ & 5814 \\
\hline Poz-77571 & Padul-15-05 & Plant remains & 186.08 & $5530 \pm 40$ & $6281-6402$ & 6341 \\
\hline Poz-74345 & Padul-15-05 & Plant remains & 199.33 & $6080 \pm 40$ & $6797-7154$ & 6935 \\
\hline BETA-415833 & Padul-15-05 & Org. bulk sed. & 217.36 & $6270 \pm 30$ & $7162-7262$ & 7212 \\
\hline Poz-77572 & Padul-15-05 & Org. bulk sed. & 238.68 & $7080 \pm 50$ & 7797-7999 & 7910 \\
\hline Poz-74347 & Padul-15-05 & Plant remains & 277.24 & $8290 \pm 40$ & $9138-9426$ & 9293 \\
\hline BETA-415834 & Padul-15-05 & Plant remains & 327.29 & $8960 \pm 30$ & $9932-10221$ & 10107 \\
\hline
\end{tabular}

* Sample number assigned at radiocarbon laboratory.

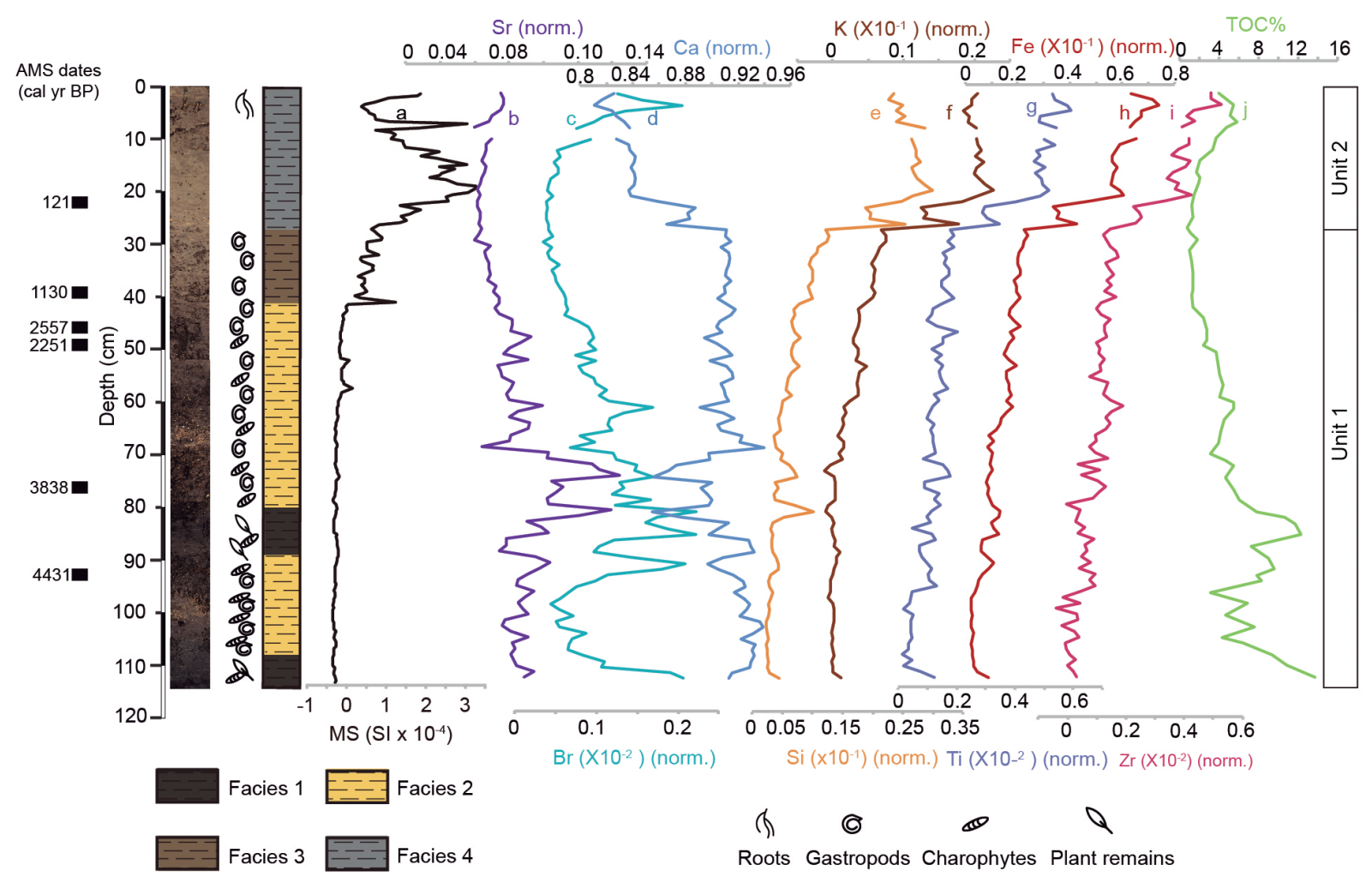

Figure 3. Lithology, facies interpretation with paleontology, magnetic susceptibility (MS), and geochemical (X-ray fluorescence, XRF) and total organic carbon (TOC) data from the Padul-15-05 record. XRF elements are represented normalized by the total counts. (a) Magnetic susceptibility (MS, SI units). (b) Strontium normalized (Sr, norm.). (c) Bromine normalized (Br, norm.). (d) Calcium normalized. (Ca, norm.). (e) Silica normalized (Si, norm.). (f) Potassium normalized (K, norm.). (g) Titanium normalized (Ti, norm.). (h) Iron normalized (Fe, norm.). (i) Zirconium normalized (Zr, norm.). (j) Total organic carbon (TOC \%). AMS radiocarbon dates (cal yr BP) are shown on the left. 
the percentage of organic carbon yielded by the elemental analyzer and recalculated by the weight of the sample prior to decalcification (Fig. 3).

\subsection{Pollen and NPP}

Samples for pollen analysis $\left(1-3 \mathrm{~cm}^{3}\right)$ were taken every $1 \mathrm{~cm}$ throughout the core, with a total of 103 samples analyzed. Pollen extraction methods followed a modified Faegri and Iversen (1989) methodology. Processing included the addition of Lycopodium spores for calculation of pollen concentration. Sediment was treated with $\mathrm{NaOH}, \mathrm{HCl}$, and $\mathrm{HF}$ and the residue was sieved at $250 \mu \mathrm{m}$ prior to an acetolysis solution. Counting was performed using a transmitted light microscope at 400 magnifications to an average pollen count of $\sim 260$ terrestrial pollen grains. Fossil pollen was identified using published keys (Beug, 2004) and modern reference collections at the University of Granada (Spain). Pollen counts were transformed to pollen percentages based on the terrestrial pollen sum, excluding aquatics. The palynological zonation was executed using cluster analysis using 11 primary pollen taxa - Olea, Pinus, deciduous Quercus, evergreen Quercus, Pistacia, Ericaceae, Artemisia, Asteroideae, Cichorioideae, Amaranthaceae, and Poaceae (Grimm, 1987) (Fig. 4). Non-pollen palynomorphs (NPPs) include fungal and algal spores and thecamoebians (testate amoebae). The NPP percentages were calculated and represented with respect to the terrestrial pollen sum (Fig. 4). Furthermore, some pollen taxa were grouped, according to present-day ecological bases, into Mediterranean forest and xerophytes (Fig. 4). The Mediterranean forest taxa are composed of Quercus total, Olea, Phillyrea, and Pistacia. The xerophyte group includes Artemisia, Ephedra, and Amaranthaceae.

\section{Results}

\subsection{Chronology and sedimentation rates}

The age model of the upper $115 \mathrm{~cm}$ of the Padul-1505 core (Fig. 2) shows an average sedimentation rate of $0.058 \mathrm{~cm} \mathrm{yr}^{-1}$ over the last $\sim 4700 \mathrm{cal} \mathrm{yr} \mathrm{BP}$, the age constrained by seven AMS ${ }^{14} \mathrm{C}$ dates (Table 1). However, average sedimentation rates of individual core segments vary from 0.01 to $0.16 \mathrm{~cm} \mathrm{yr}^{-1}$ (Fig. 2), showing the lowest values between $\sim 51$ and $40 \mathrm{~cm}$ (from $\sim 2600$ to $1350 \mathrm{cal} \mathrm{yr} \mathrm{BP}$ ) and the highest values during the last $\sim 20 \mathrm{~cm}$ (last century).

\subsection{Lithology, MS, XRF, and TOC}

The stratigraphy of the upper $\sim 115 \mathrm{~cm}$ of the Padul-15-05 sediment core was deduced primarily by visual inspection. However, our visual inspections were supported by comparison with the element geochemical composition (XRF), the MS of the split cores, and TOC (Fig. 3) to determine shifts in sediment facies. The lithology for this sedimentary sequence consists of clays with variable carbonates, siliciclastics, and organic content (Fig. 3). We also used a linear $r$ (Pearson) correlation to calculate the relationship for the XRF data. The correlation for the inorganic geochemical elements determined two different groups of elements that covary (Table 2): Group (1) $\mathrm{Si}, \mathrm{K}, \mathrm{Ti}, \mathrm{Fe}$, and $\mathrm{Zr}$ have a high positive correlation between them; Group (2) $\mathrm{Ca}, \mathrm{Br}$, and $\mathrm{Sr}$ have a negative correlation with Unit 1 . Based on this, the sequence is subdivided in two principal sedimentary units. The lower $\sim 87 \mathrm{~cm}$ of the record is designated to Unit 1 , characterized principally by relatively low values of MS and higher values of $\mathrm{Ca}$. The upper $28 \mathrm{~cm}$ of the sequence is designated to Unit 2, in which the mineralogical composition is lower in Ca with higher values of MS in correlation with mostly siliciclastics elements ( $\mathrm{Si}, \mathrm{K}, \mathrm{Ti}, \mathrm{Fe}$, and $\mathrm{Zr}$ ).

Within these two units, four different facies can be identified by visual inspection and by the elemental geochemical composition and TOC of the sediments. Facies 1 (115$110 \mathrm{~cm}$ depth, $\sim 4700$ to $4650 \mathrm{cal}$ yr BP; $89-80 \mathrm{~cm}$ depth $\sim 4300$ to 4000 cal yr BP) is characterized by dark brown organic clays that bear charophytes and macroscopic plant remains. They have also depicted relatively higher TOC values (Fig. 3). Facies $2(110-89 \mathrm{~cm}$ depth $\sim 4650$ to 4300 cal yr BP; $80-42 \mathrm{~cm}$ depth, $\sim 4000$ to $1600 \mathrm{cal} \mathrm{yr} \mathrm{BP)}$ is composed of brown clays, with the occurrence of gastropods and charophytes. This facies is also characterized by lower TOC values. Facies 3 (42-28 cm depth, $\sim 1600$ to 400 cal yr BP) is characterized by grayish brown clays with the occurrence of gastropods, lower values of TOC, and an increasing trend in MS and siliciclastic elements. Facies 4 $(28-0 \mathrm{~cm}, \sim 400 \mathrm{cal}$ yr BP to present) is made up of light grayish brown clays and features a strong increase in siliciclastic linked to a strong increase in MS.

\subsection{Pollen and NPP}

Several terrestrial and aquatic pollen taxa were identified but only the most representative taxa are plotted here in the summary pollen diagram (Fig. 4). Selected NPP percentages are also displayed in Fig. 4. Four pollen zones (PAs) were visually identified with the help of a cluster analysis using the program CONISS (Grimm, 1987). Pollen concentration was higher during Unit 1 with a decreasing trend in the transition to Unit 2 and a later increase during the pollen subzone PA-4b (Fig. 4). Pollen zones are described below.

\subsubsection{Zone PA-1 ( 4720 to 3400 cal $\mathrm{yr} \mathrm{BP} / \sim 2800$ to 1450 BCE, $115-65 \mathrm{~cm})$}

Zone 1 is characterized by the abundance of Mediterranean forest species reaching up to $\sim 70 \%$. Another important taxon in this zone is Pinus, with average values around $18 \%$. Herbs are largely represented by Poaceae, averaging around $10 \%$ and reaching up to $\sim 25 \%$. This pollen zone is subdivided into PA-1a, PA-1b, and PA-1c (Fig. 4). The 


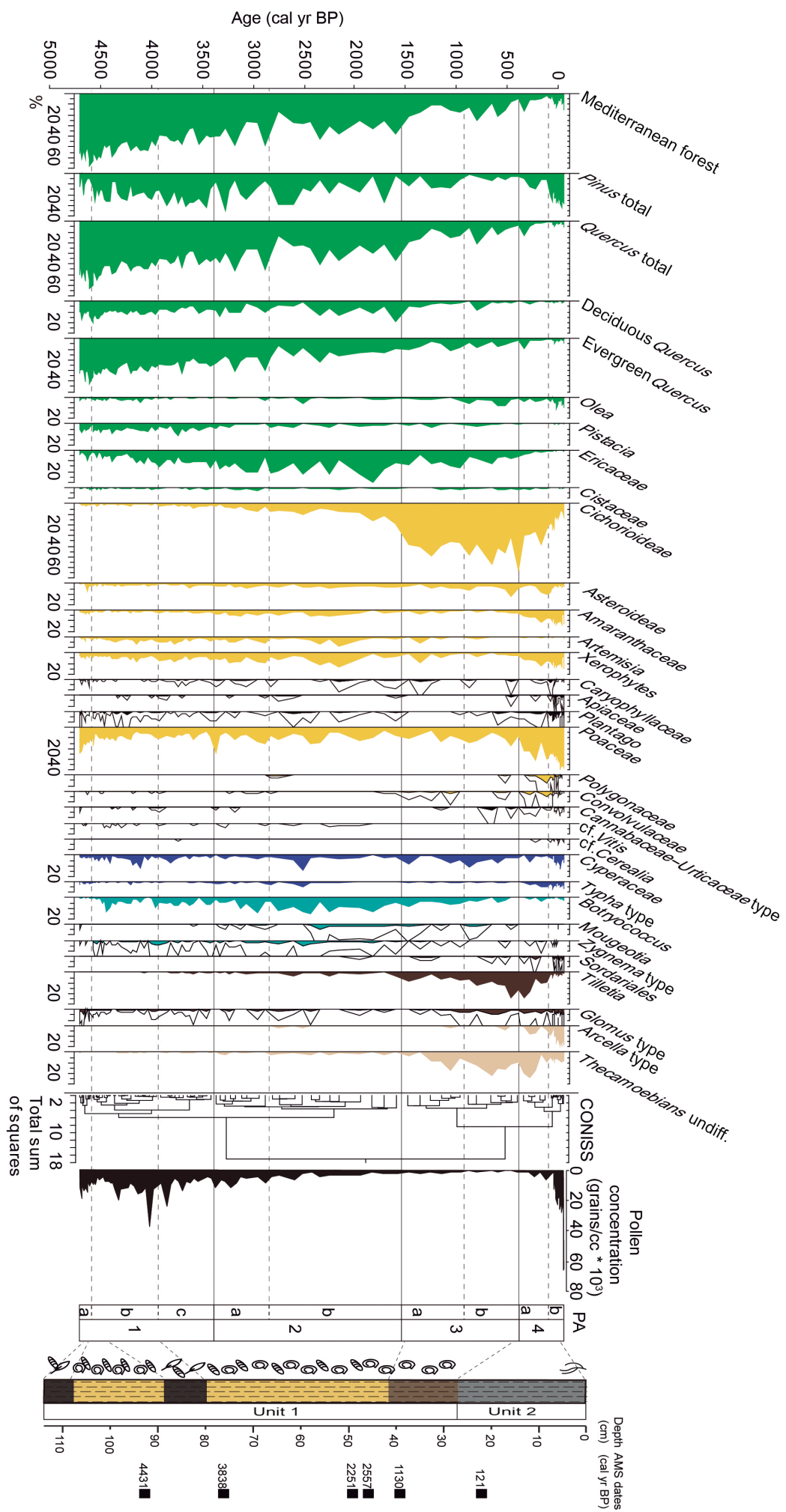

Figure 4. Percentages of selected pollen taxa and non-pollen palynomorphs (NPPs) from the Padul-15-05 record, calculated with respect to terrestrial pollen sum. Silhouettes show $7 \times$ exaggerations of pollen percentages. Pollen zonation, pollen concentration (grains/cc), lithology, and AMS radiocarbon dates are shown on the right. Trees and shrubs are shown in green, herbs and grasses in yellow, aquatics in dark blue, algae in blue, fungi in brown, and thecamoebians in beige. The Mediterranean forest taxa category is composed of Quercus total, Olea, Phillyrea, and Pistacia. The xerophyte group includes Artemisia, Ephedra, and Amaranthaceae. PA: pollen zones. 
Table 2. Linear $r$ (Pearson) correlation between geochemical elements from the Padul-15-05 record. Statistical treatment was performed using the Past software (http://palaeo-electronica.org/2001_1/past/issue1_01.htm).

\begin{tabular}{|c|c|c|c|c|c|c|c|c|}
\hline & $\mathrm{Si}$ & $\mathrm{K}$ & $\mathrm{Ca}$ & $\mathrm{Ti}$ & $\mathrm{Fe}$ & $\mathrm{Zr}$ & $\mathrm{Br}$ & $\mathrm{Sr}_{1}$ \\
\hline $\mathrm{Si}$ & & $8.30 \times 10^{-80}$ & $2.87 \times 10^{-34}$ & $7.47 \times 10^{-60}$ & $3.22 \times 10^{-60}$ & $5.29 \times 10^{-44}$ & 0.001152 & $7.79 \times 10^{-9}$ \\
\hline K & 0.98612 & & $7.07 \times 10^{-29}$ & $6.05 \times 10^{-60}$ & $8.20 \times 10^{-68}$ & $1.77 \times 10^{-51}$ & 0.00030317 & $5.38 \times 10^{-12}$ \\
\hline $\mathrm{Ca}$ & -0.88096 & -0.84453 & & $6.09 \times 10^{-42}$ & $5.81 \times 10^{-39}$ & $8.10 \times 10^{-34}$ & 0.35819 & 0.26613 \\
\hline $\mathrm{Ti}$ & 0.96486 & 0.96501 & -0.91794 & & $1.74 \times 10^{-74}$ & $1.12 \times 10^{-57}$ & 0.074223 & $8.88 \times 10^{-7}$ \\
\hline $\mathrm{Fe}$ & 0.96546 & 0.97577 & -0.90527 & 0.98224 & & $2.77 \times 10^{-66}$ & 0.051072 & $3.32 \times 10^{-8}$ \\
\hline $\mathrm{Zr}$ & 0.92566 & 0.94789 & -0.8783 & 0.96109 & 0.97398 & & 0.054274 & $7.16 \times 10^{-8}$ \\
\hline $\mathrm{Br}$ & -0.31739 & -0.3506 & -0.091917 & -0.17755 & -0.19372 & -0.19116 & & $4.03 \times 10^{-18}$ \\
\hline $\mathrm{Sr}$ & -0.53347 & -0.61629 & 0.11113 & -0.46426 & -0.51386 & -0.50295 & 0.72852 & \\
\hline
\end{tabular}

principal characteristic that differentiates PA-1a from PA-1b (boundary at $\sim 4650 \mathrm{cal} \mathrm{yr} \mathrm{BP} / 2700 \mathrm{BCE}$ ) is the decrease in Poaceae, the increase in Pinus, and the appearance of cf. Vitis. The subsequent decrease in Mediterranean forest pollen to average values around $40 \%$, the increase in Pinus to an average $\sim 25 \%$, and a progressive increase in Ericaceae to $\sim 6$ to $11 \%$ distinguishes subzone PA-1b from PA-1c (boundary at 23950 cal yr BP).

\subsubsection{Zone PA-2 ( 3400 to $1550 \mathrm{cal} \mathrm{yr} \mathrm{BP} / \sim 1450 \mathrm{BCE}$ to $400 \mathrm{CE}, 65-41 \mathrm{~cm})$}

The main features of this zone are the increase in Ericaceae up to $\sim 16 \%$ and some herbs such as Cichorioideae becoming more abundant, reaching average percentages of $\sim 7 \%$. This pollen zone can be subdivided in subzones PA-2a and PA-2b with a boundary at $\sim 2850$ cal yr BP $(\sim 900 \mathrm{BCE})$. The principal characteristics that differentiate these subzones are marked by the increasing trend in Ericaceae and deciduous Quercus reaching maximum values of $\sim 30$ and $\sim 20 \%$, respectively. In addition, the increase in Botryococcus, which averages from $\sim 4$ to $9 \%$, is an important distinction. Also notable is the expansion of Mougeotia and Zygnema types.

\subsubsection{Zone PA-3 ( 1550 to 400 cal yr BP/ 400 to $1550 \mathrm{CE}, 41-29 \mathrm{~cm})$}

This zone is distinguished by the continuing decline of Mediterranean forest elements. Cichorioideae reached average values of about $40 \%$, which is paralleled by the decrease in Ericaceae. A decline in Botryococcus and other algal remains is also observed in this zone, although there is an increase in total Thecamoebians from an average of $<1$ to $10 \%$. This pollen zone is subdivided into subzones PA-3a and PA-3b at $\sim 1000$ cal yr BP $(\sim 950 \mathrm{CE})$. The main feature that differentiates these subzones is the increase in Olea from subzone PA-3a to PA-3b from average values of $\sim 1$ to $5 \%$. The increasing trend in Poaceae is also a feature in this subzone, as well as the slight increase in Asteroideae at the top. Significant changes are documented in NPP percentages in this subzone with the increase in some fungal remains such as
Tilletia and Glomus type. Furthermore, a decrease in Botryococcus and the near disappearance of other algal remains such as Mougeotia occurred.

\subsubsection{Zone PA-4 ( last 400 cal yr BP/ 1550 CE to present, $29-0 \mathrm{~cm})$}

The main feature in this zone is the significant increase in Pinus, reaching maximum values of $\sim 32 \%$, an increase in Poaceae to $\sim 40 \%$, and the decrease in Cichorioideae ( $\sim 44$ to $16 \%)$. Other important changes are the nearly total disappearance of some shrubs such as Pistacia and a decreasing trend in Ericaceae, as well as a further decline in Mediterranean forest pollen. An increase in wetland pollen taxa, mostly Typha, also occurred. A significant increase in xerophytes, mostly Amaranthaceae to $\sim 14 \%$, is also observed in this period. Other herbs such as Plantago, Polygonaceae, and Convolvulaceae show moderate increases. PA4 is subdivided into subzones PA-4a and PA-4b (Fig. 4). The top of the record (PA-4b), which corresponds with the last $\sim 120$ years, is differentiated from subzone PA-4a (from $\sim 400-120$ cal yr BP) by a decline in some herbs such as Cichorioideae. However, an increase in other herbs such as Amaranthaceae and Poaceae occurred. The increase in Plantago is also significant during this period. PA-4b also has a noteworthy increase in Pinus (from $\sim 14$ to $27 \%$ ), and a slight increase in Olea and the evergreen Quercus are also characteristic of this subzone. With respect to NPPs, thecamoebians such as Arcella type and the largely coprophilous sordariaceous (Sordariales) spores also increase. This zone also documents the decrease in freshwater algal spores, in Botryococcus concomitant with Mougeotia and Zygnema type.

\subsection{Estimated lake level reconstruction}

Different local proxies from the Padul-15-05 record ( $\mathrm{Si}$, Ca, TOC, MS, hygrophytes (Cyperaceae and Typha), Poaceae, and algae (including Botryococcus, Zygnema types, and Mougeotia) groups) have been depicted in order to understand the relationship between lithological, geochemical, 


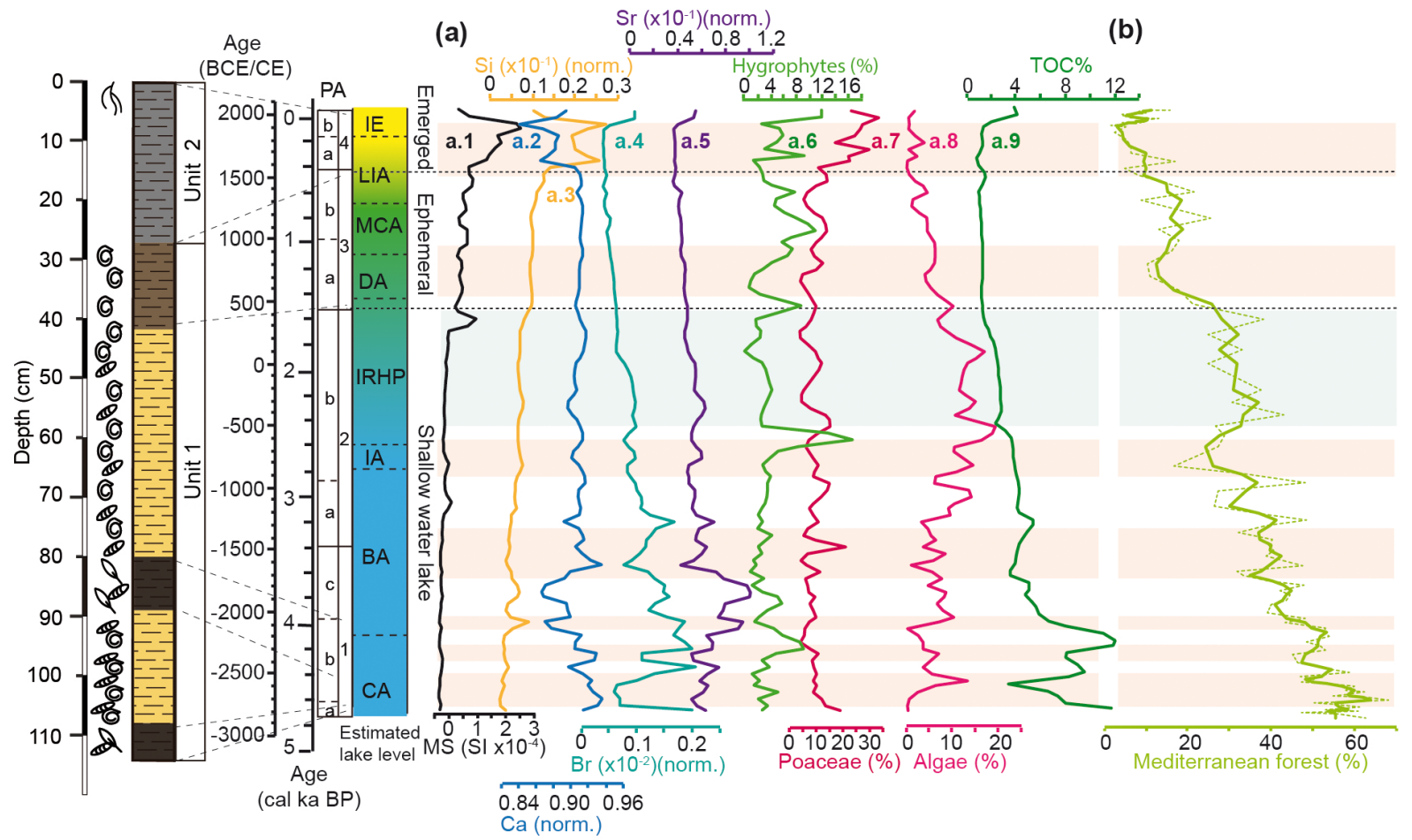

Figure 5. Estimated lake level evolution and regional palynological component from the last $\sim 4700$ years based on the synthesis of determinate proxies from the Padul-15-05 record. (a) Proxies used to estimate the water table evolution from the Padul-15-05 record (proxies were resampled at 50 years (lineal interpolation) using Past software http://palaeo-electronica.org/2001_1/past/issue1_01.htm). (a.1) Magnetic susceptibility (MS) in SI; (a.2) silica normalized (Si, norm.); (a.3) calcium normalized (Ca, norm.); (a.4) bromine normalized (Br, norm.); (a.5) strontium normalized (Sr, norm.); (a.6) hygrophytes (\%); (a.7) Poaceae (\%); (a.8) algae (\%); (a.9) total organic carbon (TOC \%). (b) Mediterranean forest taxa, with a smoothing of three points in bold. Pink and blue shading indicates Holocene arid and humid regional events, respectively. See the body of the text for the explanation of the lake level reconstruction. Mediterranean forest smoothing was made using AnalySeries software (Paillard et al., 1996). PA: pollen zones; CA: Copper Age; BA: Bronze Age; IA: Iron Age; IRHP: Iberian-Roman Humid Period; DA: Dark Ages; MCA: Medieval Climate Anomaly; LIA: Little Ice Age; IE: industrial era.

and palynological variability and the water lake level oscillations. Sediments with higher values of TOC (more algae and hygrophytes) and rich in $\mathrm{Ca}$ (related to the occurrence of shells and charophyte remains) most likely characterized a shallow water environment (Unit 1). The continuous decline in Botryococcus, the disappearance of charophytes, and the progressive increase in detritics (increase in MS and Si values) could be associated with a shallower and even ephemeral lake environment (transition from Unit 1 to Unit 2; $\sim 41$ to $28 \mathrm{~cm}$ ). The absence of aquatic remains, almost disappearance of Botryococcus, decreasing $\mathrm{Ca}$, a lower TOC, and/or a higher input of clastic material (higher MS and $\mathrm{Si}$ values) into the lake could be related with lake level lowering and even emerged conditions (increase in Poaceae; Unit 2) (Fig. 5).

\subsection{Spectral analysis}

Spectral analysis was performed on selected pollen and NPP time series (Mediterranean forest and Botryococcus), as well as TOC, in order to identify millennial- and centennial-scale periodicities. The mean sampling resolution for pollen and NPP is $\sim 50$ years and $\sim 80$ years for geochemical data. Statistically significant cycles, above the 90,95 , and $99 \%$ confidence levels, were found around 800, 680, 300, 240, 200, and 170 years (Fig. 7).

\section{Discussion}

Numerous proxies have been used in this study to interpret the paleoenvironmental and hydrodynamic changes recorded in the Padul sedimentary record during the last 4700 cal yr BP. Palynological analysis (pollen and NPP) is commonly used as a proxy for vegetation and climate change, lake level variations, human impact, and land use (e.g., van Geel et al., 1983; Faegri and Iversen, 1989). Disentangling natural vs. anthropogenic effects on the environment in the last millenniums is sometimes challenging but can be achieved using a multiproxy approach (Roberts et al., 2011; Sadori et al., 2011). In this study, we used the variations between Mediterranean forest taxa, xerophytes, and algal communities for paleoclimatic variability and the occurrence of 
nitrophilous and ruderal plant communities and some NPPs for identifying human influence in the study area. Variations in arboreal pollen (AP, including Mediterranean tree species) have previously been used in Sierra Nevada records as a proxy for humidity changes (Jiménez-Moreno and Anderson, 2012; Ramos-Román et al., 2016). The increase or decrease in Mediterranean forest species has been used as a proxy for climate change in other studies in the western Mediterranean region, with greater forest development generally meaning higher humidity (Fletcher and Sánchez-Goñi, 2008; Fletcher et al., 2013). Conversely, increases in xerophyte pollen taxa (i.e., Artemisia, Ephedra, Amaranthaceae) have been used as an indication of aridity in this area (Carrión et al., 2007; Anderson et al., 2011).

The Chlorophyceae alga Botryococcus sp. has been used as an indicator of freshwater environments in relatively productive fens temporary pools, ponds, or lakes (Guy-Ohlson, 1992). The high visual and statistical correlation between Botryococcus from Padul-15-05 and North Atlantic temperature estimations (Bond et al., 2001; $r=-0.63 ; p<0.0001$; between $\sim 4700$ and 1500 cal yr BP and $r=-0.48 ; p<0.0001$ between 4700 and -65 cal yr BP; the decreasing and very low Botryococcus occurrence in the last 1500 cal yr BP makes this correlation moderate) seems to show that in this case Botryococcus is driven by temperature change and would reflect variations in lake productivity (increasing with warmer water temperatures).

Human impact can be investigated using several palynomorphs. Nitrophilous and ruderal pollen taxa, such as Convolvulus, Plantago lanceolata type, Urticaceae type, and Polygonum aviculare type, are often proxies for human impact (Riera et al., 2004), and abundant Amaranthaceae has also been used (Sadori et al., 2013). Some species of Cichorioideae have been described as nitrophilous taxa (AbelSchaad and López-Sáez, 2013) and as grazing indicators (Mercuri et al., 2006; Florenzano et al., 2015; Sadori et al., 2016). At the same time, NPP taxa such as some coprophilous fungi, Sordariales, and thecamoebians are also used as indicators of anthropization and land use (van Geel et al., 1989; Riera et al., 2006; Carrión et al., 2007; Ejarque et al., 2015). Tilletia a grass-parasitizing fungi has been described as an indicator of grass cultivation in other Iberian records (Carrión et al., 2001a). In this study we follow the example of others (van Geel et al., 1989; Morellón et al., 2016; Sadori et al., 2016) who used the NPP soil mycorrhizal fungus Glomus sp. as a proxy for erosive activity.

The palynological analysis, variations in the lithology, geochemistry, and macrofossil remains (gastropod shells and charophytes) from the Padul-15-05 core helped us reconstruct the estimated lake level and the local environmental changes in the Padul area and their relationship with regional climate (Fig. 5). Several previous studies on late Holocene lake records from the Iberian Peninsula show that lithological changes can be used as a proxy for lake level reconstruction (Riera et al., 2004; Morellón et al., 2009; Martín-Puertas et al., 2011). For example, carbonate sediments formed by biogenic remains of gastropods and charophytes are indicative of shallow lake waters (Riera et al., 2004). Furthermore, van Geel et al. (1983) described occurrences of Mougeotia and Zygnema type (Zygnemataceae) as typical of shallow water environments. The increase in organic matter accumulation deduced by TOC (and Br) could be considered as characteristic of high productivity (Kalugin et al., 2007) in these shallow water environments. Conversely, increases in clastic input in lake sediments have been interpreted as due to lowering of lake level and more influence of terrestrial-fluvial deposition in a very shallow and ephemeral lake (Martín-Puertas et al., 2008). Carrión (2002) related the increase in some fungal species and Asteraceae as an indicator of seasonal desiccation stages in lakes. Nevertheless, in natural environments with potential interactions with human activities the increase in clastic deposition related to other indications of soil erosion (e.g., Glomus sp.) may be assigned to intensification in land use (Morellón et al., 2016; Sadori et al., 2016).

\subsection{Late Holocene aridification trend}

Our work confirms the progressive aridification trend that occurred during at least the last $\sim 4700$ cal yr BP on the southern Iberian Peninsula, as shown here by the progressive decrease in Mediterranean forest and the increase in herbs (Figs. 4 and 6). Our lake level interpretations agree with the pollen data, showing an overall decrease during the late Holocene, from a shallow water table containing relatively abundant organic matter (high TOC, indicating higher productivity), gastropods, and charophytes (high Ca values) to a less productive ephemeral and emerged environment (high clastic input and MS and decrease in Ca) (Fig. 5). This natural progressive aridification confirmed by the decrease in Mediterranean forest taxa and increase in siliciclastics pointing to a change towards ephemeral (even emerged) environments became more prominent at about $1550 \mathrm{cal} \mathrm{yr} \mathrm{BP}$ and has then enhanced again since $\sim 400 \mathrm{cal}$ yr BP to present. A clear increase in human land use is also observed during the last $\sim 1550$ cal yr BP (see bellow), including abundant Glomus from erosion, which shows that humans were at least partially responsible for this sedimentary change.

A suite of proxy previous studies supports our conclusions regarding the aridification trend since the middle Holocene (Carrión, 2002; Carrión et al., 2010; Fletcher and SánchezGoñi, 2008; Fletcher et al., 2013; Jiménez-Espejo et al., 2014; Jiménez-Moreno et al., 2015). In the western Mediterranean region the decline in forest development during the middle and late Holocene is related to a decrease in summer insolation (Jiménez-Moreno and Anderson, 2012; Fletcher et al., 2013), which may have decreased winter rainfall as a consequence of a northward shift of the westerlies - a long-term enhanced positive NAO trend - which has induced drier conditions in this area since $\sim 6000 \mathrm{cal} \mathrm{yr}$ BP (Magny et al., 2012). Furthermore, the decrease in summer insolation 


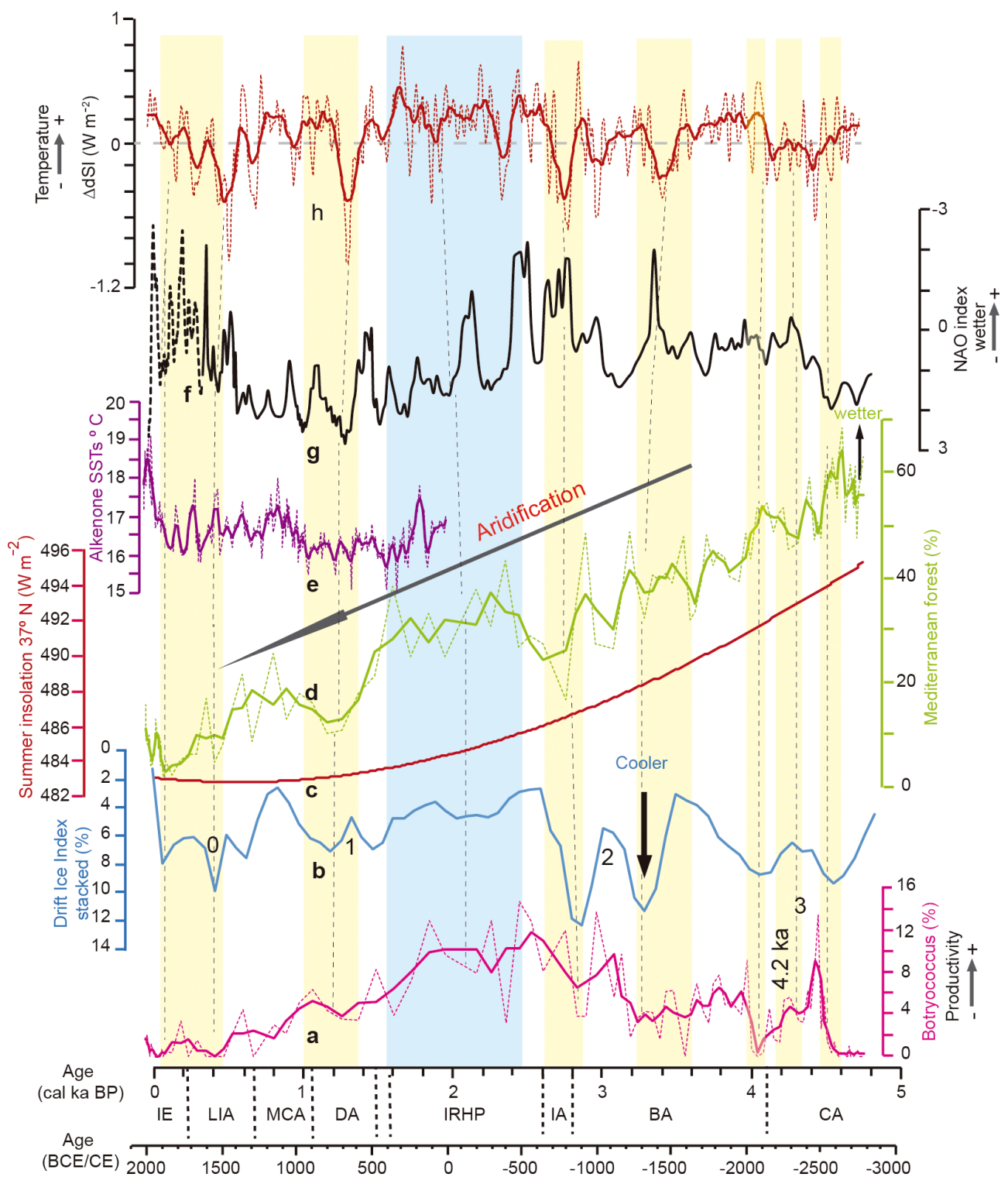

Figure 6. Comparison of the last $\sim 4700$ years between different pollen taxa from the Padul-15-05 record, summer insolation for the Sierra Nevada latitude, eastern Mediterranean humidity, and North Atlantic temperature. (a) Botryococcus from the Padul-15-05 record, with a smoothing of three points in bold (this study). (b) Drift ice index (reversed) from the North Atlantic (Bond et al., 2001). (c) Summer insolation calculated for $37^{\circ} \mathrm{N}$ (Laskar et al., 2004). (d) Mediterranean forest taxa from the Padul-15-05 record, with a smoothing of three points in bold (this study). (e) Alkenone SSTs from the Gulf of Lion (Sicre et al., 2016), with a smoothing of four points in bold. (f) NAO index from a climate proxy reconstruction from Morocco and Scotland (Trouet et al., 2009). (g) North Atlantic Oscillation (NAO) index (reversed) from a climate proxy reconstruction from Greenland (Olsen et al., 2012). (h) Total solar irradiance reconstruction from cosmogenic radionuclide from a Greenland ice core (Steinhilber et al., 2009), with a smoothing of 21 points in bold. Note that the magnitude of the different curves is not in the same scale. Yellow and blue shading corresponds with arid (and cold) and humid (and warm) periods, respectively. Grey dashed lines show a tentative correlation between arid and cold conditions and the decrease in the Mediterranean forest and Botryococcus. Mediterranean forest, Botryococcus , and solar irradiance smoothing was made using AnalySeries software (Paillard et al., 1996); alkenone SST smoothing was made using Past software (http://palaeo-electronica.org/2001_1/past/issue1_01.htm). A linear $r$ (Pearson) correlation was calculated between Botryococcus (detrended) and the drift ice index (Bond et al., 2001; $r=-0.63 ; p<0.0001$; between $\sim 4700$ and 1500 cal ka BP $-r=-0.48 ; p<0.0001$; between 4700 and -65 cal yr BP). Previously, the data were detrended (only in Botryococcus), resampled at 70 years (linear interpolation) in order to obtain equally spaced time series, and smoothed to a three-point average. CA: Copper Age; BA: Bronze Age; IA: Iron Age; IRHP: Iberian-Roman Humid Period; DA: Dark Ages; MCA: Medieval Climate Anomaly; LIA: Little Ice Age; IE: industrial era. 
(a) Mediterranean forest taxa

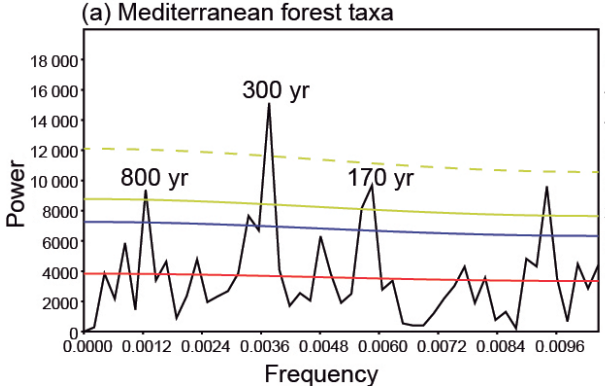

(b) Botryococcus

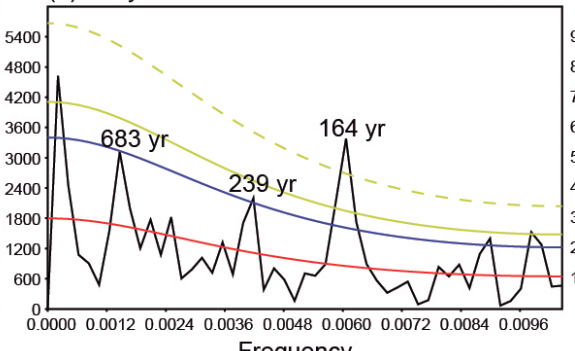

(c) TOC

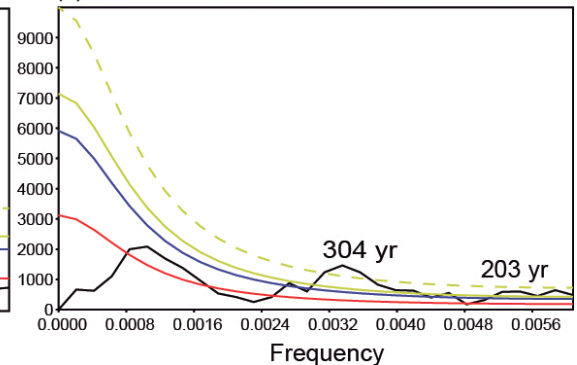

Figure 7. Spectral analysis of (a) Mediterranean forest taxa and (b) Botryococcus (mean sampling space is 47 years) and (c) TOC (mean sampling space is 78 years) from Padul-15-05. The significant periodicities above confidence level are shown. The confidence level is at $90 \%$ (blue line), $95 \%$ (green line), $99 \%$ (green dash line), and autoregressive (1) red noise (red line). Spectral analysis was made with Past software (http://palaeo-electronica.org/2001_1/past/issue1_01.htm).

would produce a progressive cooling, with a reduction in the length of the growing season as well as a decrease in the sea surface temperature (SST; Marchal et al., 2002), generating a decrease in the land-sea contrast that would be reflected in a reduction of the wind system and a reduced precipitation gradient from sea to shore during the fall-winter season. The aridification trend can clearly be seen in the nearby alpine records from the Sierra Nevada, where there was little influence from human activity (Anderson et al., 2011; JiménezMoreno and Anderson, 2012; Jiménez-Moreno et al., 2013; Ramos-Román et al., 2016).

\subsection{Millennial- and centennial-scale climate variability in the Padul area during the late Holocene}

The multiproxy paleoclimate record from Padul-15-05 shows an overall aridification trend. However, this trend seems to be modulated by millennial- and centennial-scale climatic variability.

\subsubsection{Aridity pulses around $4200(4500,4300$, and 4000 cal yr BP) and around 3000 cal yr BP (3300 and 2800 cal yr BP)}

Marked aridity pulses are registered in the Padul-15-05 record around 4200 and $3000 \mathrm{cal} \mathrm{yr} \mathrm{BP}$ (Unit 1; PA-1 an PA-2a; Figs. 5 and 6). These arid pulses are mostly evidenced in this record by declines in Mediterranean forest taxa as well as lake level drops and/or cooling evidenced by a decrease in the organic component as TOC and the decrease in Botryococcus algae. However, a discrepancy between the local and regional signals occurs between 3000 and 2800 cal yr BP, with an increase in the estimated lake level and a decrease in the Mediterranean forest during the late Bronze Age until the early Iron Age (Figs. 5 and 6). The disagreement could be due to deforestation by humans during a very active period of mining in the area observed as a peak in lead pollution in the alpine records from Sierra Nevada (García-Alix et al., 2013). The aridity pulses agree region- ally with recent studies carried out at a higher elevation in the Sierra Nevada, a decrease in AP percentage in the Borreguil de la Caldera record around 4000-3500 cal yr BP (RamosRomán et al., 2016), a high percentage of non-arboreal pollen around 3400 cal ka BP in Zoñar lake (Southern Córdoba Natural Reserve; Martín-Puertas et al., 2008), and lake desiccation at $\sim 4100$ and $2900 \mathrm{cal} \mathrm{yr} \mathrm{BP}$ in Lake Siles (Carrión et al., 2007). Jalut et al. (2009) compared paleoclimatic records from different lakes in the western Mediterranean region and also suggested a dry phase between 4300 and $3400 \mathrm{cal} \mathrm{yr} \mathrm{BP,}$ synchronous with this aridification phase. Furthermore, in the eastern Mediterranean Basin other pollen studies show a decrease in arboreal pollen concentration toward more open landscapes around $4 \mathrm{cal} \mathrm{ka} \mathrm{BP} \mathrm{(Magri,} \mathrm{1999).}$

Significant climatic changes also occurred in the Northern Hemisphere at those times: polar cooling and tropical aridity are observed at $\sim 4200-3800$ and $3500-2500$ cal yr BP; (Mayewski et al., 2004), cold events in the North Atlantic (cold event 3 and 2; Bond et al., 2001), decrease in solar irradiance (Steinhilber et al., 2009) and humidity decreases in the eastern Mediterranean area at $4200 \mathrm{cal} \mathrm{yr} \mathrm{BP} \mathrm{(Bar-}$ Matthews et al., 2003), which could be related to globalscale climate variability (Fig. 6). These generally dry phases between 4.5 and 2.8 in Padul-15-05 are generally in agreement with persistent positive NAO conditions during this time (Olsen et al., 2012).

The high-resolution Padul-15-05 record shows that climatic crises such as the essentially global event at $\sim 4200$ cal yr BP (Booth et al., 2005) are actually multiple events in climate variability on centennial scales (i.e., $\sim 4500,4300,4000$ cal yr BP).

\subsubsection{Iberian-Roman Humid Period ( 2600 to 1600 cal yr BP)}

High relative humidity is recorded in the Padul-15-05 record between $\sim 2600$ and 1600 cal yr BP, synchronous with the well-known Iberian-Roman Humid Period (IRHP; between 2600 and 1600 cal yr BP; Martín-Puertas et al., 2009). This is 
interpreted in our record due to an increase in the Mediterranean forest species at that time (Unit 1; PA-2b; Fig. 6). In addition, there is a simultaneous increase in Botryococcus algae, which is probably related to higher productivity during warmer conditions and relatively higher water level. A minimum in sedimentary rates at this time is also recorded, probably related with lower detritic input caused by less erosion due to afforestation and probably also related to the decrease in TOC due to less organic accumulation in the sediment. Evidence of a wetter climate around this period has also been shown in several alpine records from the Sierra Nevada. For example, in the Laguna de la Mula core (Jiménez-Moreno et al., 2013) an increase in deciduous Quercus is correlated with the maximum in algae between 2500 and $1850 \mathrm{cal}$ yr BP, also evidencing the most humid period of the late Holocene. A geochemical study from the Laguna de Río Seco (also in the Sierra Nevada) also evidenced humid conditions around 2200 cal yr BP with the decrease in Saharan dust input and the increase in detritic sedimentation into the lake, suggesting higher rainfall (Jiménez-Espejo et al., 2014). In addition, Ramos-Román et al. (2016) showed an increase in AP in the Borreguil de la Caldera record around 2200 cal yr BP, suggesting an increase in humidity at that time.

Other records from the Iberian Peninsula also show this pattern of wetter conditions during the IRHP. For example, high lake levels are recorded in Zoñar Lake in southern Spain between 2460 and 1600 cal yr BP, only interrupted by a relatively arid pulse between 2140 and 1800 cal yr BP (MartínPuertas et al., 2009). An increase in rainfall is described in the central region of the Iberian Peninsula in a study from the Tablas de Daimiel National Park between 2100 and 1680 cal yr BP (Gil García et al., 2007). Deeper lake levels at around 2650 to $1580 \mathrm{cal} \mathrm{yr} \mathrm{BP}$, also interrupted by a short arid event at $\sim 2125-1790 \mathrm{cal}$ yr BP, were observed to the north in the Iberian Range (Currás et al., 2012). The fact that the Padul-15-05 record also shows a relatively arid-cold event between 2150 and 2050 cal yr BP, just in the middle of this relatively humid and warm period, seems to point to a common feature of centennial-scale climatic variability in many western Mediterranean and North Atlantic records (Fig. 6). Humid climate conditions at around 2500 cal yr BP are also interpreted in previous studies from lake level reconstructions from central Europe (Magny, 2004). Increases in temperate deciduous forest are also observed in marine records from the Alboran Sea around 2600 to $2300 \mathrm{cal} \mathrm{yr} \mathrm{BP,}$ also pointing to high relative humidity (Combourieu Nebout et al., 2009). Overall humid conditions between 2600 and 1600 cal yr BP seem to agree with predominant negative NAO reconstructions at that time, which would translate into greater winter (and thus more effective) precipitation in the area, triggering greater development of forest species in the area.

Generally warm conditions are interpreted between 1900 and 1700 cal yr BP in the Mediterranean Sea with high SSTs and in the North Atlantic area with the decrease in the drift ice index. In addition, persistent positive solar irradiance occurred at that time. The increase in Botryococcus algae reaching maxima during the IRHP also seems to point to very productive and perhaps warmer conditions in the Padul area (Fig. 6). There seems to be a short lag of about 200 years between maximum in Botryococcus and maximum in Mediterranean forest. This could be due to different speeds of reaction to climate change, with algae (short life cycle, blooming if conditions are favorable) responding faster than forest (tree development takes decades). An alternative explanation could be that they might be responding to different forcings, with the regional signal (forest) mostly conditioned by precipitation and local signal (algae) also conditioned by temperature (productivity).

\subsubsection{DA and MCA ( 1550 to 600 cal yr BP $)$}

Enhanced aridity occurred right after the IRHP in the Padul area. This is deduced in the Padul-15-05 record by a significant forest decline, with a prominent decrease in Mediterranean forest elements and an increase in herbs (Unit 1; PA3; Figs. 4 and 6). In addition, our evidence suggests a transition from a shallow lake to a more ephemeral wetland. This is suggested by the disappearance of charophytes, a significant decrease in the algae component, higher Si and MS values, and lower TOC values (Unit 1; Fig. 5). Humans probably also contributed to enhancing erosion in the area during this last $\sim 1550$ cal yr BP. The significant change during the transition from Unit 1 to Unit 2 with a decrease in the pollen concentration and an increase in Cichorioideae could be due to enhanced pollen degradation as Cichorioideae have been found to be very resistant to pollen deterioration (Bottema, 1975). However, the occurrence of other pollen taxa (e.g., Quercus, Ericaceae, Pinus, Poaceae, Olea) showing climatic trends and increasing between $\sim 1500$ and 400 cal yr BP and a decrease in Cichorioideae in the last $\sim 400$ cal yr BP, when an increase in clastic material occurred, does not entirely support a preservation issue (see Sect. 5.4).

This phase could be separated into two different periods. The first period occurred between $\sim 1550$ and 1100 cal yr BP ( $\sim 400$ to $900 \mathrm{CE}$ ) and is characterized by a decreasing trend in Mediterranean forest and Botryococcus taxa. This period corresponds with the Dark Ages (DA, from 500 to $900 \mathrm{CE}$; Moreno et al., 2012). Correlation between the decline in Mediterranean forest, the increase in the drift ice index in the North Atlantic record (cold event 1; Bond et al., 2001), the decline in SSTs in the Mediterranean Sea, and maxima in positive NAO reconstructions suggests drier and colder conditions during this time (Fig. 6). Other Mediterranean and central European records agree with our climate interpretations. For example, a decrease in forest pollen types is shown in a marine record from the Alboran Sea (Fletcher et al., 2013) and a decrease in lake levels is also observed in central Europe (Magny et a., 2004), pointing to aridity during the DA. Evidence of aridity during the DA has also been 
shown in the Mediterranean part of the Iberian Peninsula; for instance, cold and arid conditions were suggested in the northern Betic Cordillera by the increase in xerophytic herbs around 1450 and 750 cal yr BP (Carrión et al., 2001b) and in southeastern Spain by a forest decline in lacustrine deposits around 1620 and 1160 cal yr BP (Carrión et al., 2003). Arid and colder conditions during the DA (around 1680 to 1000 cal yr BP) are also suggested for the central part of the Iberian Peninsula using a multiproxy study of a sediment record from the Tablas de Daimiel Lake (Gil García et al., 2007).

A second period that we could differentiate occurred around 1100 to $600 \mathrm{cal} \mathrm{yr} \mathrm{BP/900} \mathrm{to} 1350 \mathrm{CE}$, during the well-known Medieval Climate Anomaly (MCA, 900 to 1300 CE after Moreno et al., 2012). During this period the Padul-15-05 record shows a slight increasing trend in the Mediterranean forest taxa with respect to the DA, but the decrease in Botryococcus and the increase in herbs still point to overall arid conditions. This change could be related to an increase in temperature, favoring the development of temperate forest species, and would agree with inferred increasing temperatures in the North Atlantic areas as well as the increase in solar irradiance and the increase in SSTs in the Mediterranean Sea (Fig. 6). This hypothesis would agree with the reconstruction of persistent positive NAO and overall warm conditions during the MCA in the western Mediterranean (see synthesis in Moreno et al., 2012). A similar pattern of increasing xerophytic vegetation during the MCA is observed in alpine peat bogs and lakes in the Sierra Nevada (Anderson et al., 2011; Jiménez-Moreno et al., 2013; Ramos-Román et al., 2016), and arid conditions are shown to occur during the MCA on the southern and eastern Iberian Peninsula deduced by increases in salinity and lower lake levels (MartínPuertas et al., 2011; Corella et al., 2013). However, humid conditions have been reconstructed for the northwest of the Iberian Peninsula (Lebreiro et al., 2006; Moreno et al., 2012) as well as northern Europe at this time (Martín-Puertas et al., 2008). The different pattern of precipitation between northwestern Iberia-northern Europe and the Mediterranean area is undoubtedly a function of the NAO precipitation dipole (Trouet et al., 2009).

\subsubsection{The last $\sim 600$ cal yr BP: LIA $(\sim 600$ to $100 \mathrm{cal}$ yr BP/ 1350 to $1850 \mathrm{CE}$ ) and IE ( $\sim 100$ cal yr BP to present/ 1850 CE-present)}

Two climatically distinct periods can be distinguished during the last $\sim 600$ years (end of PA-3b to PA-4; Fig. 4) in the area. However, the climatic signal is more difficult to interpret due to a higher human impact at that time. The first phase around $600-500 \mathrm{cal}$ yr BP was characterized as increasing relative humidity by the decrease in xerophytes and the increase in Mediterranean forest taxa and Botryococcus after a period of decrease during the DA and MCA, corresponding to the Little Ice Age (LIA). The second phase is character- ized here by the decrease in the Mediterranean forest around $300-100$ cal yr BP, pointing to a return to more arid conditions during the last part of the LIA (Figs. 5 and 6). This climatic pattern agrees with an increase in precipitation from the transition from positive to negative NAO mode and from warmer to cooler conditions in the North Atlantic area during the first phase of the LIA and a second phase characterized by cooler (cold event 0 ; Bond et al., 2001) and drier conditions (Fig. 6). A stronger variability in SSTs is described in the Mediterranean Sea during the LIA (Fig. 6). Mayewski et al. (2004) described a period of climate variability during the Holocene at this time (600 to $150 \mathrm{cal} \mathrm{yr} \mathrm{BP}$ ), suggesting a polar cooling but more humid in some parts of the tropics. Regionally, Morellón et al. (2011) also described a phase of more humid conditions between 1530 and $1750 \mathrm{CE}$ (420 to $200 \mathrm{cal} \mathrm{yr} \mathrm{BP)} \mathrm{in} \mathrm{a} \mathrm{lake} \mathrm{sediment} \mathrm{record} \mathrm{from} \mathrm{NE} \mathrm{Spain.} \mathrm{An}$ alternation between wetter and drier periods during the LIA are also shown in the nearby alpine record from Borreguil de la Caldera in the Sierra Nevada mountain range (RamosRomán et al., 2016).

The environmental transition from ephemeral, observed in the last $\sim 1550$ cal yr BP (Unit 1; Fig. 5), to emerged conditions occurs in the last $\sim 400 \mathrm{cal}$ yr BP. This is shown by the highest MS and $\mathrm{Si}$ values, enhanced sedimentation rates, the increase in wetland plants, and the stronger decrease in $\mathrm{Ca}$ and organic components (TOC) in the sediments in the uppermost part of the Padul-15-05 record (Unit 2; Figs. 3 and 5).

\subsection{Centennial-scale variability}

Time series analysis has become important in determining the recurrent periodicity of cyclical oscillations in paleoenvironmental sequences (e.g., Fletcher et al., 2013; JiménezEspejo et al., 2014; Rodrigo-Gámiz et al., 2014; RamosRomán et al., 2016). This analysis also assists in understanding possible relationships between the paleoenvironmental proxy data and the potential triggers of the observed cyclical changes: i.e., solar activity, atmospheric and oceanic dynamics, and climate evolution during the Holocene. The cyclostratigraphic analysis on the pollen (Mediterranean forest; regional signal), algae (Botryococcus; local signal), and TOC (local signal) times series from the Padul-15-05 record evidence centennial-scale cyclical patterns with periodicities around $\sim 800,680,300,240,200$, and 170 years above the $90 \%$ confidence levels (Fig. 7).

Previous cyclostratigraphic analysis in Holocene western Mediterranean records suggest cyclical climatic oscillations with periodicities around 1500 and 1750 years (Fletcher et al., 2013; Jiménez-Espejo et al., 2014; Rodrigo-Gámiz et al., 2014). Other North Atlantic and Mediterranean records also present cyclicities of $\sim 1600$ years in their paleoclimatic proxies (Bond et al., 2001; Debret et al., 2007; RodrigoGámiz et al., 2014). However, this cycle is absent from the cyclostratigraphic analysis in the Padul-15-05 record (Fig. 7). 
In contrast, the spectral analysis performed on the Mediterranean forest time series from the Padul record, pointing to cyclical hydrological changes, shows a significant $\sim 800$ year cycle that could be related to solar variability (Damon and Sonett, 1991) or could be the second harmonic of the $\sim 1600$-year ocean-related cycle (Debret et al., 2009). A very similar periodicity of $\sim 760$ years is detected in the Pinus forest taxa, also pointing to humidity variability, from the alpine Sierra Nevada site of Borreguil de la Caldera and seems to show that this is a common feature of cyclical paleoclimatic oscillation in the area.

A significant $\sim 680$-year cycle is shown in the Botryococcus time series, most likely suggesting recurrent centennialscale changes in temperature (productivity) and water availability. A similar cycle is shown in the Artemisia signal in an alpine record from the Sierra Nevada (Ramos-Román et al., 2016). This cycle around $\sim 650$ years is also observed in a marine record from the Alboran Sea and was interpreted as the secondary harmonic of the 1300-year cycle that those authors related with cyclic thermohaline circulation and sea surface temperature changes (Rodrigo-Gámiz et al., 2014).

A statistically significant $\sim 300$-year cycle is shown in the Mediterranean forest taxa and TOC from the Padul-15-05 record, suggesting shorter-scale variability in water availability. This cycle is also observed in the cyclical Pinus pollen data from Borreguil de la Caldera at higher elevations in the Sierra Nevada (Ramos-Román et al., 2016). This cycle could be principally related to NAO variability as observed by Olsen et al. (2012), which follows variations in humidity observed in the Padul-15-05 record. NAO variability also regulates modern precipitation in the area.

The Botryococcus and TOC time series show variability with a periodicity around $\sim 240,200$, and 164 years. Sonett and Suess (1984) described a significant cycle in solar activity around $\sim 208$ years (Suess solar cycle), which could have triggered our $\sim 200$-year cyclicity. The observed $\sim 240$-year periodicity in the Padul-15-05 record could be either related to variations in solar activity or due to the mixed effect of the solar cycle together with the $\sim 300$-year NAO-interpreted cycle and could point to a solar origin of the centennialscale NAO variations as suggested by previously published research (Lukianova and Alekseev, 2004; Zanchettin et al., 2008). Finally, a significant $\sim 170$-year cycle has been observed in both the Mediterranean forest taxa and Botryococcus times series from the Padul-15-05 record. A similar cycle (between 168 and 174 years) was also described in the alpine pollen record from Borreguil de la Caldera in the Sierra Nevada (Ramos-Román et al., 2016), which shows that it is a significant cyclical pattern in climate, and probably precipitation, in the area. This cycle could be related to the previously described $\sim 170$-year cycle in the NAO index (Olsen et al., 2012), which would agree with the hypothesis of the NAO controlling millennial- and centennial-scale environmental variability during the late Holocene in the area (Ramos-Román et al., 2016; García-Alix et al., 2017).

\subsection{Human activity}

Humans have probably had an impact on the area since prehistoric times; however, the Padul-15-05 multiproxy record shows a more significant human impact during the last $\sim 1550$ cal yr BP, which intensified in the last $\sim 500$ years (since $1450 \mathrm{CE}$ to present). This is deduced by a significant increase in nitrophilous plant taxa such as Cichorioideae, Convolvulaceae, Polygonaceae, and Plantago and the increase in some NPPs such as Tilletia, coprophilous fungi, and thecamoebians (Unit 2; PA-4; Fig. 4). Most of these pollen taxa and NPPs are described in other southern Iberian paleoenvironmental records as indicators of land uses; for instance, Tilletia and covarying nitrophilous plants have been described as indicators of farming (e.g., Carrión et al., 2001a). Thecamoebians also show a similar trend and have also been detected in other areas being related to nutrient enrichment as consequences of livestock (Fig. 8). The stronger increase in Cichorioideae has also been described as an indicator of animal grazing in areas subjected to intense use of the territory (Mercuri et al., 2006). Interestingly, these taxa began to decline around 400 cal yr BP $(\sim 1550 \mathrm{CE})$, coinciding with the higher increase in detritic material in the basin. We could then interpret this increase in Cichorioideae as coming from increased livestock activity in the surroundings of the lake during this period, which is supported by the increase in these other proxies related with animal husbandry.

Climatically, this event coincides with the start of persistent negative NAO conditions in the area (Trouet et al., 2009), which could have further triggered more rainfall and more detritic input into the basin. Bellin et al. (2011) in a study from the Betic Cordillera (southern Iberian Peninsula) demonstrate that soil erosion increases in years with higher rainfall and this could be intensified by human impact. Nevertheless, a study in the southeastern part of the Iberian Peninsula (Bellin et al., 2013) suggested that major soil erosion could have occurred from the abandonment of agricultural activities in the mountain areas as well as the abandonment of irrigated terrace systems during the Christian Reconquest. Enhanced soil erosion at this time is also supported by the increase in Glomus type (Figs. 4 and 8).

An important change in the sedimentation in the environment is observed during the last $\sim 400 \mathrm{cal}$ yr BP, marked by the stronger increase in MS and Si values. This higher increase in detritics occurred during an increase in other plants related to human and land uses such as Polygonaceae, Amaranthaceae, Convolvulaceae, Plantago, Apiaceae, and Cannabaceae-Urticaceae type (land use plants; Fig. 8). This was probably related to drainage canals in the Padul wetland in the late 18th century for cultivation purposes (Villegas Molina, 1967). The increase in wetland vegetation and higher values of Poaceae could be due to cultivation of cereals or an increase in the population of Phragmites australis 


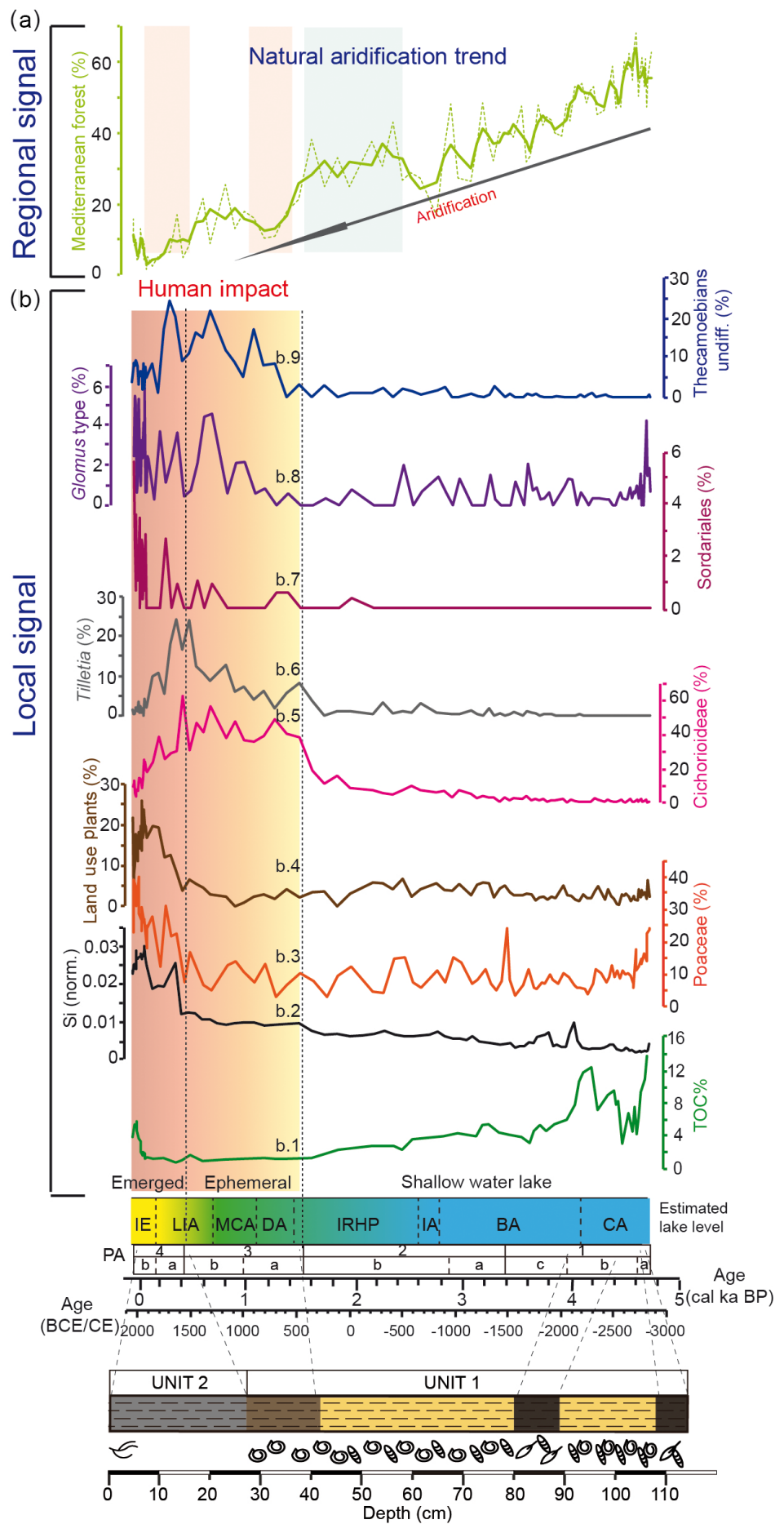

Figure 8. Comparison of the last $\sim 4700$ years between regional climatic proxies and local human activity indicators from the Padul-1505 record. (a) Mediterranean forest taxa, with a smoothing of three points in bold. (b) Local human activity indicator: (b.1) total organic carbon (TOC \%), soil erosion indicator; (b.2) Si normalized (Si, norm.), soil erosion indicator; (b.3) Poaceae (\%), lake drained and/or cultivar indicator; (b.4) land use plants (\%), cultivar indicator; (b.5) Cichorioideae (\%), livestock occurrence indicator; (b.6) Tilletia (\%), farming indicator; (b.7) Sordariales (\%), livestock indicator; (b.8) Glomus type, soil erosion; (b.9) Thecamoebians undifferentiated (\%), livestock indicator. Yellow to red shading corresponds with the time when we have evidence of humans shaping the environment from $\sim 1550$ cal yr BP to present. Prior to this period there is a lack of clear evidence of human impact in the area. Land use plants is composed of Polygonaceae, Amaranthaceae, Convolvulaceae, Plantago, Apiaceae, and Cannabaceae-Urticaceae type. CA: Copper Age; BA: Bronze Age; IA: Iron Age; IRHP: Iberian-Roman Humid Period; DA: Dark Ages; MCA: Medieval Climate Anomaly; LIA: Little Ice Age; IE: industrial era. 
(also a Poaceae), which are very abundant in the Padul lake margins at present due to the increase in drained land surface.

The uppermost part (last $\sim 100$ cal yr BP) of the pollen record from Padul-15-05 shows an increasing trend in some arboreal taxa at that time, including Mediterranean forest, Olea, and Pinus (Fig. 4). This change is most likely of human origin and generated by the increase in Olea cultivation in the last 2 centuries, also observed in many records from higher elevation sites from the Sierra Nevada, and Pinus and other Mediterranean species reforestation in the 20th century (Anderson et al., 2011; Jiménez-Moreno and Anderson, 2012; Jiménez-Moreno et al., 2013; Ramos-Román et al., 2016). Preliminary charcoal data show maxima in charcoal particle sedimentation coinciding with maxima in forest (fuel) during the early and middle Holocene humid and warmest maxima and do not show any increase in the last millennia, supporting our conclusions about little human impact in the area until very recent (Cole Webster, personal communication, 2017). This agrees with previous studies on the area showing that Mediterranean fire regimes today are mostly conditioned by fuel load variations (Jiménez-Moreno et al., 2013; RamosRomán et al., 2016).

\section{Conclusions}

Our multiproxy analysis from the Padul-15-05 sequence has provided a detailed climate reconstruction for the last 4700 cal yr BP for the Padul area and the western Mediterranean. This study, supported by the comparison with other Mediterranean and North Atlantic records, suggests a link between vegetation, atmospheric dynamics, insolation, and solar activity during the late Holocene. A climatic aridification trend occurred during the late Holocene in the Sierra Nevada and the western Mediterranean, probably linked with an orbital-scale declining trend in summer insolation. This long-term trend is modulated by centennial-scale climate variability as shown by the pollen (Mediterranean forest taxa), algae (Botryococcus), and sedimentary and geochemical data in the Padul record. These events can be correlated with regional- and global-scale climate variability. Cold and arid pulses identified in this study around 4200 and 3000 cal yr BP are synchronous with cold events recorded in the North Atlantic and decreases in precipitation in the Mediterranean area, probably linked to a persistent positive NAO mode. Moreover, one of the most important humid and warmer periods during the late Holocene in the Padul area coincides in time with the well-known IRHP, characterized by warm and humid conditions in the Mediterranean and North Atlantic regions and overall negative NAO conditions. A drastic decline in Mediterranean forest taxa, trending towards an open landscape and pointing to colder conditions with enhanced aridity, occurred in two steps (DA and end of the LIA) during the last $\sim 1550$ cal yr BP. However, this trend was slightly superimposed by a more arid but warmer event coinciding with the MCA and a cold but wetter event during the first part of the LIA. In addition to natural climatic and environmental variability, strong evidence exists for intense human activities in the area during the last $\sim 1550$ years. This suggests that the natural aridification trend during the late Holocene, which produced a progressive decrease in the Mediterranean forest taxa in the Padul area, could have been intensified by human activities, notably in the last centuries.

Furthermore, time series analyses performed on in the Padul-15-05 record show centennial-scale changes in the environment and climate that are coincident with the periodicities observed in solar, oceanic, and NAO reconstructions and could show a close cause-and-effect linkage between them.

Data availability. The data are not publicly accessible yet because research is still ongoing in this core. Please contact the main author if interested in using these data.

Competing interests. The authors declare that they have no conflict of interest.

\section{The Supplement related to this article is available online at https://doi.org/10.5194/cp-14-117-2018-supplement.}

Acknowledgements. This work was supported by the project P11-RNM-7332 funded by Consejería de Economía, Innovación, Ciencia y Empleo de la Junta de Andalucía, the project CGL201347038-R funded by Ministerio de Economía y Competitividad of Spain and fondo Europeo de desarrollo regional FEDER and the research group RNM0190 (Junta de Andalucía). María J. Ramos-Román acknowledges the $\mathrm{PhD}$ funding provided by Consejería de Economía, Innovación, Ciencia y Empleo de la Junta de Andalucía (P11-RNM-7332). Jon Camuera acknowledges the PhD funding provided by Ministerio de Economía y Competitividad (CGL2013-47038-R). Antonio García-Alix was also supported by a Ramón y Cajal Fellowship RYC-2015-18966 of the Spanish Government (Ministerio de Economía y Competividad). Javier Jaimez (CIC-UGR) is thanked for graciously helping with the coring, the drilling equipment, and logistics. We would also like to thank Graciela Gil-Romera, Laura Sadori, and the anonymous reviewer for their comments and suggestions, which improved the paper.

Edited by: Nathalie Combourieu Nebout

Reviewed by: Graciela Gil Romera, Laura Sadori, and one anonymous referee 


\section{References}

Abel-Schaad, D. and López-Sáez, J. A.: Vegetation changes in relation to fire history and human activities at the Peña Negra mire (Bejar Range, Iberian Central Mountain System, Spain) during the past 4,000 years, Veg. Hist. Archaeobotany, 22, 199-214, https://doi.org/10.1007/s00334-012-0368-9, 2013.

Alfaro, P., Galinod-Zaldievar, J., Jabaloy, A., López-Garrido, A. C., and Sanz de Galdeano, C.: Evidence for the activity and paleoseismicity of the Padul fault (Betic Cordillera, Southern Spain) [Evidencias de actividad y paleosismicidad de la falla de Padul (Cordillera Bética, sur de España)], Acta Geol. Hisp., 36, 283297, 2001.

Alpert, P., Baldi, M., Ilani, R., Krichak, S., Price, C., Rodó, X., Saaroni, H., Ziv, B., Kishcha, P., Barkan, J., Mariotti, A., and Xoplaki, E.: Chapter 2 Relations between climate variability in the Mediterranean region and the tropics: ENSO, South Asian and African monsoons, hurricanes and Saharan dust, Dev. Earth Environ. Sci., 4, 149-177, https://doi.org/10.1016/S15719197(06)80005-4, 2006.

Anderson, R. S., Jiménez-Moreno, G., Carrión, J. S., and Pérez-Martínez, C.: Postglacial history of alpine vegetation, fire, and climate from Laguna de Río Seco, Sierra Nevada, southern Spain, Quat. Sci. Rev., 30, 1615-1629, https://doi.org/10.1016/j.quascirev.2011.03.005, 2011.

Bar-Matthews, M., Ayalon, A., Gilmour, M., Matthews, A., and Hawkesworth, C. J.: Sea-land oxygen isotopic relationships from planktonic foraminifera and speleothems in the Eastern Mediterranean region and their implication for paleorainfall during interglacial intervals, Geochim. Cosmochim. Ac., 67, 31813199, https://doi.org/10.1016/S0016-7037(02)01031-1, 2003.

Bellin, N., Vanacker, V., van Wesemael, B., Solé-Benet, A., and Bakker, M. M.: Natural and anthropogenic controls on soil erosion in the internal betic Cordillera (southeast Spain), Catena, 87, 190-200, https://doi.org/10.1016/j.catena.2011.05.022, 2011.

Bellin, N., Vanacker, V., and De Baets, S.: Anthropogenic and climatic impact on Holocene sediment dynamics in SE Spain: A review, Quat. Int., 308-309, 112-129, https://doi.org/10.1016/j.quaint.2013.03.015, 2013.

Beug, H.-J.: Leitfaden der Pollenbestimmung für Mitteleuropa und angrenzende Gebiete, Fisch. Stuttg., Leitfaden der Pollenbestimmung für Mitteleuropa und angrenzende Gebiete, Friedrich Pfeil, München, 61, 2004.

Blaauw, M.: Methods and code for "classical" age-modelling of radiocarbon sequences, Quat. Geochronol., 5, 512-518, https://doi.org/10.1016/j.quageo.2010.01.002, 2010.

Bond, G., Kromer, B., Beer, J., Muscheler, R., Evans, M. N., Showers, W., Hoffmann, S., Lotti-Bond, R., Hajdas, I., and Bonani, G.: Persistent Solar Influence on North Atlantic Climate During the Holocene, Science, 294, 2130, https://doi.org/10.1126/science.1065680, 2001.

Booth, R. K., Jackson, S. T., Forman, S. L., Kutzbach, J. E., Bettis III, E. A., Kreigs, J., and Wright, D. K.: A severe centennialscale drought in midcontinental North America 4200 years ago and apparent global linkages, The Holocene, 15, 321-328, https://doi.org/10.1191/0959683605hl825ft, 2005.

Bottema, S.: The interpretation of pollen spectra from prehistoric settlements (with special attention of Liguliflorae), Palaeohistoria, 17, 17-35, 1975.
Carrión, J. S.: Patterns and processes of Late Quaternary environmental change in a montane region of southwestern Europe, Quat. Sci. Rev., 21, 2047-2066, https://doi.org/10.1016/S02773791(02)00010-0, 2002.

Carrión, J. S., Andrade, A., Bennett, K. D., Navarro, C., and Munuera, M.: Crossing forest thresholds: inertia and collapse in a Holocene sequence from south-central Spain, The Holocene, 11, 635-653, https://doi.org/10.1191/09596830195672, 2001a.

Carrión, J. S., Munuera, M., Dupré, M., and Andrade, A.: Abrupt vegetation changes in the Segura Mountains of southern Spain throughout the Holocene, J. Ecol., 89, 783-797, https://doi.org/10.1046/j.0022-0477.2001.00601.x, 2001b.

Carrión, J. S., Sánchez-Gómez, P., Mota, J. F., Yll, R., and Chaín, C.: Holocene vegetation dynamics, fire and grazing in the Sierra de Gádor, southern Spain, The Holocene, 13, 839-849, https://doi.org/10.1191/0959683603hl662rp, 2003.

Carrión, J. S., Fuentes, N., González-Sampériz, P., Quirante, L. S., Finlayson, J. C., Fernández, S., and Andrade, A.: Holocene environmental change in a montane region of southern Europe with a long history of human settlement, Quat. Sci. Rev., 26, 14551475, https://doi.org/10.1016/j.quascirev.2007.03.013, 2007.

Carrión, J. S., Fernández, S., Jiménez-Moreno, G., Fauquette, S., Gil-Romera, G., González-Sampériz, P., and Finlayson, C.: The historical origins of aridity and vegetation degradation in southeastern Spain, J. Arid Environ., 74, 731-736, https://doi.org/10.1016/j.jaridenv.2008.11.014, 2010.

Castillo Martín, A., Benavente Herrera, J., Fernández Rubio, R., and Pulido Bosch, A.: Evolución y ámbito hidrogeológico de la laguna de Padul (Granada), Las Zonas Húmedas En Andal. Monogr. DGMA-MOPU, 1984.

Combourieu Nebout, N., Peyron, O., Dormoy, I., Desprat, S., Beaudouin, C., Kotthoff, U., and Marret, F.: Rapid climatic variability in the west Mediterranean during the last 25000 years from high resolution pollen data, Clim. Past, 5, 503-521, https://doi.org/10.5194/cp-5-503-2009, 2009.

Corella, J. P., Stefanova, V., El Anjoumi, A., Rico, E., Giralt, S., Moreno, A., Plata-Montero, A., and Valero-Garcés, B. L.: A 2500-year multi-proxy reconstruction of climate change and human activities in northern Spain: The Lake Arreo record, Palaeogeogr. Palaeoclimatol. Palaeoecol., 386, 555-568, https://doi.org/10.1016/j.palaeo.2013.06.022, 2013.

Currás, A., Zamora, L., Reed, J. M., García-Soto, E., Ferrero, S., Armengol, X., Mezquita-Joanes, F., Marqués, M. A., Riera, S., and Julià, R.: Climate change and human impact in central Spain during Roman times: High-resolution multi-proxy analysis of a tufa lake record (Somolinos, 1280m asl), Catena, 89, 31-53, https://doi.org/10.1016/j.catena.2011.09.009, 2012.

Damon, P. E. and Sonett, C. P.: Solar and terrestrial components of the atmospheric C-14 variation spectrum, in: The Sun in Time, edited by: Sonett, C. P., Giampapa, M. S., and Matthews, M. S., University of Arizona Press, Tucson, AZ, USA, 1991.

Debret, M., Bout-Roumazeilles, V., Grousset, F., Desmet, M., McManus, J. F., Massei, N., Sebag, D., Petit, J.-R., Copard, Y., and Trentesaux, A.: The origin of the 1500-year climate cycles in Holocene North-Atlantic records, Clim. Past, 3, 569-575, https://doi.org/10.5194/cp-3-569-2007, 2007. .

Debret, M., Sebag, D., Crosta, X., Massei, N., Petit, J.R., Chapron, E., and Bout-Roumazeilles, V.: Evidence from wavelet analysis for a mid-Holocene transition in 
global climate forcing, Quat. Sci. Rev., 28, 2675-2688, https://doi.org/10.1016/j.quascirev.2009.06.005, 2009.

Delgado, J., Alfaro, P., Galindo-Zaldivar, J., Jabaloy, A., Lopez Garrido, A., and Sanz de Galdeano, C.: Structure of the PadulNigüelas basin (S Spain) from H/V ratios of ambient noise: application of the method to study peat and coarse sediments, Pure Appl. Geophys., 159, 2733-2749, 2002.

Domingo-García, M., Fernández-Rubio, R., Lopez, J., and González, C.: Aportación al conocimiento de la Neotectónica de la Depresión del Padul (Granada), Tecniterrae, 53, 6-16, 1983.

Ejarque, A., Anderson, R. S., Simms, A. R., and Gentry, B. J.: Prehistoric fires and the shaping of colonial transported landscapes in southern California: A paleoenvironmental study at Dune Pond, Santa Barbara County, Quat. Sci. Rev., 112, 181196, https://doi.org/10.1016/j.quascirev.2015.01.017, 2015.

El Aallali, A., Nieto, J. M. L., Raya, F. A. P., and Mesa, J. M.: Estudio de la vegetación forestal en la vertiente sur de Sierra Nevada (Alpujarra Alta granadina), Itinera Geobot., 11, 387-402, 1998.

Faegri, K. and Iversen, J.: Textbook of Pollen Analysis, Wiley, New York, 1989.

Fletcher, W. J. and Sánchez-Goñi, M. F.: Orbital- and sub-orbitalscale climate impacts on vegetation of the western Mediterranean basin over the last 48000 year, Quat. Res., 70, 451-464, https://doi.org/10.1016/j.yqres.2008.07.002, 2008.

Fletcher, W. J., Debret, M., and Sánchez-Goñi, M. F.: MidHolocene emergence of a low-frequency millennial oscillation in western Mediterranean climate: Implications for past dynamics of the North Atlantic atmospheric westerlies, The Holocene, 23, 153-166, https://doi.org/10.1177/0959683612460783, 2013.

Florenzano, A., Marignani, M., Rosati, L., Fascetti, S., and Mercuri, A. M.: Are Cichorieae an indicator of open habitats and pastoralism in current and past vegetation studies?, Plant Biosyst. - Int. J. Deal. Asp. Plant Biol., 149, 154-165, https://doi.org/10.1080/11263504.2014.998311, 2015.

Florschütz, F., Amor, J. M., and Wijmstra, T. A.: Palynology of a thick quaternary succession in southern Spain, Palaeogeogr. Palaeoclimatol. Palaeoecol., 10, 233-264, https://doi.org/10.1016/0031-0182(71)90049-6, 1971.

García-Alix, A., Jimenez-Espejo, F. J., Lozano, J. A., JiménezMoreno, G., Martinez-Ruiz, F., Sanjuán, L. G., Jiménez, G. A., Alfonso, E. G., Ruiz-Puertas, G., and Anderson, R. S.: Anthropogenic impact and lead pollution throughout the Holocene in Southern Iberia, Sci. Total Environ., 449, 451-460, https://doi.org/10.1016/j.scitotenv.2013.01.081, 2013.

García-Alix, A., Jiménez-Espejo, F. J., Toney, J. L., JiménezMoreno, G., Ramos-Román, M. J., Anderson, R. S., Ruano, P., Queralt, I., Delgado Huertas, A., and Kuroda, J.: Alpine bogs of southern Spain show human-induced environmental change superimposed on long-term natural variations, Sci. Rep., 7, 7439, https://doi.org/10.1038/s41598-017-07854-w, 2017.

Gil García, M. J., Ruiz Zapata, M. B., Santisteban, J. I., Mediavilla, R., López-Pamo, E., and Dabrio, C. J.: Late holocene environments in Las Tablas de Daimiel (south central Iberian peninsula, Spain), Veg. Hist. Archaeobotany, 16, 241-250, https://doi.org/10.1007/s00334-006-0047-9, 2007.

Gil-Romera, G., Carrión, J. S., Pausas, J. G., SevillaCallejo, M., Lamb, H. F., Fernández, S., and Burjachs, F.: Holocene fire activity and vegetation response in
South-Eastern Iberia, Quat. Sci. Rev., 29, 1082-1092, https://doi.org/10.1016/j.quascirev.2010.01.006, 2010.

Grimm, E. C.: CONISS: a FORTRAN 77 program for stratigraphically constrained cluster analysis by the method of incremental sum of squares, Comput. Geosci., 13, 13-35, https://doi.org/10.1016/0098-3004(87)90022-7, 1987.

Guy-Ohlson, D.: Botryococcus as an aid in the interpretation of palaeoenvironment and depositional processes, Rev. Palaeobot. Palynol., 71, 1-15, https://doi.org/10.1016/00346667(92)90155-A, 1992.

Hurrell, J. W.: Decadal Trends in the North Atlantic Oscillation: Regional Temperatures and Precipitation, Science, 269, 676, https://doi.org/10.1126/science.269.5224.676, 1995.

Jalut, G., Dedoubat, J. J., Fontugne, M., and Otto, T.: Holocene circum-Mediterranean vegetation changes: Climate forcing and human impact, Quat. Int., 200, 4-18, https://doi.org/10.1016/j.quaint.2008.03.012, 2009.

Jiménez-Espejo, F. J., García-Alix, A., Jiménez-Moreno, G., Rodrigo-Gámiz, M., Anderson, R. S., Rodríguez-Tovar, F. J., Martínez-Ruiz, F., Giralt, S., Delgado Huertas, A., and Pardo-Igúzquiza, E.: Saharan aeolian input and effective humidity variations over western Europe during the Holocene from a high altitude record, Chem. Geol., 374-375, 1-12, https://doi.org/10.1016/j.chemgeo.2014.03.001, 2014.

Jiménez-Moreno, G. and Anderson, R. S.: Holocene vegetation and climate change recorded in alpine bog sediments from the Borreguiles de la Virgen, Sierra Nevada, southern Spain, Quat. Res., 77, 44-53, https://doi.org/10.1016/j.yqres.2011.09.006, 2012.

Jiménez-Moreno, G., García-Alix, A., Hernández-Corbalán, M. D., Anderson, R. S., and Delgado-Huertas, A.: Vegetation, fire, climate and human disturbance history in the southwestern Mediterranean area during the late Holocene, Quat. Res., 79, 110-122, https://doi.org/10.1016/j.yqres.2012.11.008, 2013.

Jiménez-Moreno, G., Rodríguez-Ramírez, A., Pérez-Asensio, J. N., Carrión, J. S., López-Sáez, J. A., Villarías-Robles, J. J. R., Celestino-Pérez, S., Cerrillo-Cuenca, E., León, Á., and Contreras, C.: Impact of late-Holocene aridification trend, climate variability and geodynamic control on the environment from a coastal area in SW Spain, Holocene, 25, 607-617, https://doi.org/10.1177/0959683614565955, 2015.

Kalugin, I., Daryin, A., Smolyaninova, L., Andreev, A., Diekmann, B., and Khlystov, O.: 800-yr-long records of annual air temperature and precipitation over southern Siberia inferred from Teletskoye Lake sediments, Quat. Res., 67, 400-410, https://doi.org/10.1016/j.yqres.2007.01.007, 2007.

Laskar, J., Robutel, P., Joutel, F., Gastineau, M., Correia, A. C. M., and Levrard, B.: A long-term numerical solution for the insolation quantities of the Earth, Astron. Astrophys., 428, 261-285, https://doi.org/10.1051/0004-6361:20041335, 2004.

Lebreiro, S. M., Francés, G., Abrantes, F. F. G., Diz, P., Bartels-Jónsdóttir, H. B., Stroynowski, Z. N., Gil, I. M., Pena, L. D., Rodrigues, T., Jones, P. D., Nombela, M. A., Alejo, I., Briffa, K. R., Harris, I., and Grimalt, J. O.: Climate change and coastal hydrographic response along the Atlantic Iberian margin (Tagus Prodelta and Muros Ría) during the last two millennia, Holocene, 16, 1003-1015, https://doi.org/10.1177/0959683606hl990rp, 2006.

Lillios, K. T., Blanco-González, A., Drake, B. L., and López-Sáez, J. A.: Mid-late Holocene climate, demography, and cultural dy- 
namics in Iberia: A multi-proxy approach, Quat. Sci. Rev., 135, 138-153, https://doi.org/10.1016/j.quascirev.2016.01.011, 2016. López-Sáez, J. A., Abel-Schaad, D., Pérez-Díaz, S., BlancoGonzález, A., Alba-Sánchez, F., Dorado, M., Ruiz-Zapata, B., Gil-García, M. J., Gómez-González, C., and Franco-Múgica, F.: Vegetation history, climate and human impact in the Spanish Central System over the last 9000 years, Quat. Int., 353, 98-122, https://doi.org/10.1016/j.quaint.2013.06.034, 2014.

Lukianova, R. and Alekseev, G.: Long-Term Correlation Between the Nao and Solar Activity, Sol. Phys., 224, 445-454, https://doi.org/10.1007/s11207-005-4974-x, 2004.

Magny, M.: Holocene climate variability as reflected by midEuropean lake-level fluctuations and its probable impact on prehistoric human settlements, Quat. Int., 113, 65-79, https://doi.org/10.1016/S1040-6182(03)00080-6, 2004.

Magny, M., Peyron, O., Sadori, L., Ortu, E., Zanchetta, G., Vannière, B., and Tinner, W.: Contrasting patterns of precipitation seasonality during the Holocene in the southand north-central Mediterranean, J. Quat. Sci., 27, 290-296, https://doi.org/10.1002/jqs.1543, 2012.

Magri, D.: Late Quaternary vegetation history at Lagaccione near Lago di Bolsena (central Italy), Rev. Palaeobot. Palynol., 106, 171-208, https://doi.org/10.1016/S0034-6667(99)00006-8, 1999.

Marchal, O., Cacho, I., Stocker, T. F., Grimalt, J. O., Calvo, E., Martrat, B., Shackleton, N., Vautravers, M., Cortijo, E., Van Kreveld, S., Andersson, C., Koç, N., Chapman, M., Sbaffi, L., Duplessy, J.-C., Sarnthein, M., Turon, J.-L., Duprat, J., and Jansen, E.: Apparent long-term cooling of the sea surface in the northeast Atlantic and Mediterranean during the Holocene, Quat. Sci. Rev., 21, 455-483, https://doi.org/10.1016/S02773791(01)00105-6, 2002.

Martín-Puertas, C., Valero-Garcés, B. L., Mata, M. P., GonzálezSampériz, P., Bao, R., Moreno, A., and Stefanova, V.: Arid and humid phases in southern Spain during the last 4000 years: the Zoñar Lake record, Córdoba, The Holocene, 18, 907-921, https://doi.org/10.1177/0959683608093533, 2008.

Martín-Puertas, C., Valero-Garcés, B. L., Brauer, A., Mata, M. P., Delgado-Huertas, A., and Dulski, P.: The Iberian-Roman Humid Period (2600-1600 cal yr BP) in the Zoñar Lake varve record (Andalucía, southern Spain), Quat. Res., 71, 108-120, https://doi.org/10.1016/j.yqres.2008.10.004, 2009.

Martín-Puertas, C., Valero-Garcés, B. L., Mata, M. P., Moreno, A., Giralt, S., Martínez-Ruiz, F., and Jiménez-Espejo, F.: Geochemical processes in a Mediterranean Lake: A high-resolution study of the last 4000 years in Zoñar Lake, southern Spain, J. Paleolimnol., 46, 405-421, https://doi.org/10.1007/s10933-0099373-0, 2011.

Mayewski, P. A., Rohling, E. E., Stager, J. C., Karlén, W., Maasch, K. A., Meeker, L. D., Meyerson, E. A., Gasse, F., van Kreveld, S., Holmgren, K., Lee-Thorp, J., Rosqvist, G., Rack, F., Staubwasser, M., Schneider, R. R., and Steig, E. J.: Holocene climate variability, Quat. Res., 62, 243-255, https://doi.org/10.1016/j.yqres.2004.07.001, 2004.

Mercuri, A. M., Accorsi, C. A., Mazzanti, M. B., Bosi, G., Cardarelli, A., Labate, D., Marchesini, M., and Grandi, G. T.: Economy and environment of Bronze Age settlements - Terramaras on the Po Plain (Northern Italy): first results from the archaeobotanical research at the Terramara di Montale, Veg. Hist. Ar- chaeobotany, 16, 43, https://doi.org/10.1007/s00334-006-0034$1,2006$.

Morellón, M., Valero-Garcés, B., Vegas-Vilarrúbia, T., GonzálezSampériz, P., Romero, Ó., Delgado-Huertas, A., Mata, P., Moreno, A., Rico, M., and Corella, J. P.: Lateglacial and Holocene palaeohydrology in the western Mediterranean region: The Lake Estanya record (NE Spain), Quat. Sci. Rev., 28, 25822599, https://doi.org/10.1016/j.quascirev.2009.05.014, 2009.

Morellón, M., Valero-Garcés, B., González-Sampériz, P., VegasVilarrúbia, T., Rubio, E., Rieradevall, M., Delgado-Huertas, A., Mata, P., Romero, Ó., Engstrom, D. R., López-Vicente, M., Navas, A., and Soto, J.: Climate changes and human activities recorded in the sediments of Lake Estanya (NE Spain) during the Medieval Warm Period and Little Ice Age, J. Paleolimnol., 46, 423-452, https://doi.org/10.1007/s10933-009-9346-3, 2011.

Morellón, M., Anselmetti, F. S., Ariztegui, D., Brushulli, B., Sinopoli, G., Wagner, B., Sadori, L., Gilli, A., and Pambuku, A.: Human-climate interactions in the central Mediterranean region during the last millennia: The laminated record of Lake Butrint (Albania), Spec. Issue Mediterr. Holocene Clim. Environ. Hum. Soc., 136(Supplement C), 134-152, https://doi.org/10.1016/j.quascirev.2015.10.043, 2016.

Moreno, A., Cacho, I., Canals, M., Grimalt, J. O., Sánchez-Goñi, M. F., Shackleton, N., and Sierro, F. J.: Links between marine and atmospheric processes oscillating on a millennial time-scale. A multi-proxy study of the last 50,000 year from the Alboran Sea (Western Mediterranean Sea), Quat. Sci. Rev., 24, 1623-1636, https://doi.org/10.1016/j.quascirev.2004.06.018, 2005.

Moreno, A., Pérez, A., Frigola, J., Nieto-Moreno, V., RodrigoGámiz, M., Martrat, B., González-Sampériz, P., Morellón, M., Martín-Puertas, C., Corella, J. P., Belmonte, Á., Sancho, C., Cacho, I., Herrera, G., Canals, M., Grimalt, J. O., Jiménez-Espejo, F., Martínez-Ruiz, F., Vegas-Vilarrúbia, T., and Valero-Garcés, B. L.: The Medieval Climate Anomaly in the Iberian Peninsula reconstructed from marine and lake records, Quat. Sci. Rev., 43, 16-32, https://doi.org/10.1016/j.quascirev.2012.04.007, 2012.

Nestares, T. and Torres, T. de: Un nuevo sondeo de investigación paleoambiental del Pleistoceno y Holoceno en la turbera del Padul (Granada, Andalucía), Geogaceta 23, 99-102, 1997.

Olsen, J., Anderson, N. J., and Knudsen, M. F.: Variability of the North Atlantic Oscillation over the past 5,200 years, Nat. Geosci., 5, 808-812, https://doi.org/10.1038/ngeo1589, 2012.

Ortiz, J. E., Torres, T., Delgado, A., Julià, R., Lucini, M., Llamas, F. J., Reyes, E., Soler, V., and Valle, M.: The palaeoenvironmental and palaeohydrological evolution of Padul Peat Bog (Granada, Spain) over one million years, from elemental, isotopic and molecular organic geochemical proxies, Org. Geochem., 35, 1243-1260, https://doi.org/10.1016/j.orggeochem.2004.05.013, 2004.

Paillard, D., Labeyrie, L., and Yiou, P.: Macintosh Program performs time-series analysis, Eos Trans. Am. Geophys. Union, 77, 379-379, https://doi.org/10.1029/96EO00259, 1996.

Pérez Raya, F. and López Nieto, J.: Vegetación acuática y helofítica de la depresión de Padul (Granada), Acta Bot Malacit., 16, 373389, 1991.

Pons, A. and Reille, M.: The holocene- and upper pleistocene pollen record from Padul (Granada, Spain): A new study, Palaeogeogr. Palaeoclimatol. Palaeoecol., 66, 243-263, https://doi.org/10.1016/0031-0182(88)90202-7, 1988. 
Ramos-Román, M. J., Jiménez-Moreno, G., Anderson, R. S., García-Alix, A., Toney, J. L., Jiménez-Espejo, F. J., and Carrión, J. S.: Centennial-scale vegetation and North Atlantic Oscillation changes during the Late Holocene in the southern Iberia, Quat. Sci. Rev., 143, 84-95, https://doi.org/10.1016/j.quascirev.2016.05.007, 2016.

Reimer, P. J., Bard, E., Bayliss, A., Beck, J. W., Blackwell, P. G., Ramsey, C. B., Buck, C. E., Cheng, H., Edwards, R. L., Friedrich, M., Grootes, P. M., Guilderson, T. P., Haflidason, H., Hajdas, I., Hatté, C., Heaton, T. J., Hoffmann, D. L., Hogg, A. G., Hughen, K. A., Kaiser, K. F., Kromer, B., Manning, S. W., Niu, M., Reimer, R. W., Richards, D. A., Scott, E. M., Southon, J. R., Staff, R. A., Turney, C. S. M., and van der Plicht, J.: IntCal13 and Marine13 Radiocarbon Age Calibration Curves 0-50,000 Years cal BP, Radiocarbon, 55, 1869-1887, https://doi.org/10.2458/azu_js_rc.55.16947, 2013.

Riera, S., Wansard, G., and Julià, R.: 2000-year environmental history of a karstic lake in the Mediterranean PrePyrenees: the Estanya lakes (Spain), CATENA, 55, 293-324, https://doi.org/10.1016/S0341-8162(03)00107-3, 2004.

Riera, S., López-Sáez, J. A., and Julià, R.: Lake responses to historical land use changes in northern Spain: The contribution of non-pollen palynomorphs in a multiproxy study, Rev. Palaeobot. Palynol., 141, 127-137, https://doi.org/10.1016/j.revpalbo.2006.03.014, 2006.

Roberts, N., Brayshaw, D., Kuzucuoğlu, C., Perez, R., and Sadori, L.: The mid-Holocene climatic transition in the Mediterranean: Causes and consequences, The Holocene, 21, 3-13, https://doi.org/10.1177/0959683610388058, 2011.

Rodrigo-Gámiz, M., Martínez-Ruiz, F., Rodríguez-Tovar, F. J., Jiménez-Espejo, F. J., and Pardo-Igúzquiza, E.: Millennial- to centennial-scale climate periodicities and forcing mechanisms in the westernmost Mediterranean for the past 20,000 year, Quat. Res., 81, 78-93, https://doi.org/10.1016/j.yqres.2013.10.009, 2014.

Sadori, L., Jahns, S., and Peyron, O.: Mid-Holocene vegetation history of the central Mediterranean, The Holocene, 21, 117-129, https://doi.org/10.1177/0959683610377530, 2011.

Sadori, L., Ortu, E., Peyron, O., Zanchetta, G., Vanniére, B., Desmet, M., and Magny, M.: The last 7 millennia of vegetation and climate changes at Lago di Pergusa (central Sicily, Italy), Clim. Past, 9, 1969-1984, https://doi.org/10.5194/cp-91969-2013, 2013.

Sadori, L., Giraudi, C., Masi, A., Magny, M., Ortu, E., Zanchetta, G., and Izdebski, A.: Climate, environment and society in southern Italy during the last 2000 years. A review of the environmental, historical and archaeological evidence, Spec. Issue Mediterr. Holocene Clim. Environ. Hum. Soc., 136, 173-188, https://doi.org/10.1016/j.quascirev.2015.09.020, 2016.
Sanz de Galdeano, C., El Hamdouni, R., and Chacón, J.: Neotectónica de la fosa del Padul y del Valle de Lecrín, Itiner. Geomorfológicos Por Andal. Orient. Publicacions Univ. Barc. Barc., 65-81, 1998.

Sicre, M.-A., Jalali, B., Martrat, B., Schmidt, S., Bassetti, M.A., and Kallel, N.: Sea surface temperature variability in the North Western Mediterranean Sea (Gulf of Lion) during the Common Era, Earth Planet. Sci. Lett., 456, 124-133, https://doi.org/10.1016/j.epsl.2016.09.032, 2016.

Sonett, C. P. and Suess, H. E.: Correlation of bristlecone pine ring widths with atmospheric $14 \mathrm{C}$ variations: a climate-Sun relation, Nature, 307, 141-143, https://doi.org/10.1038/307141a0, 1984.

Steinhilber, F., Beer, J., and Fröhlich, C.: Total solar irradiance during the Holocene, Geophys. Res. Lett., 36, , 19, https://doi.org/10.1029/2009GL040142, 2009.

Trouet, V., Esper, J., Graham, N. E., Baker, A., Scourse, J. D., and Frank, D. C.: Persistent Positive North Atlantic Oscillation Mode Dominated the Medieval Climate Anomaly, Science, 324, 78-80, https://doi.org/10.1126/science.1166349, 2009.

Valle, F.: Mapa de series de vegetación de Andalucía 1: 400000 , Editorial Rueda, Madrid, 2003.

Valle Tendero, F.: Modelos de Restauración Forestal: Datos botánicos aplicados a la gestión del Medio Natural Andaluz II: Series de vegetación, Cons. Medio Ambiente Junta Andal. Sevilla, 2004.

van Geel, B., Hallewas, D. P., and Pals, J. P.: A late holocene deposit under the Westfriese Zeedijk near Enkhuizen (Prov. of Noord-Holland, The Netherlands): Palaeoecological and archaeological aspects, Rev. Palaeobot. Palynol., 38, 269-335, https://doi.org/10.1016/0034-6667(83)90026-X, 1983.

van Geel, B., Coope, G. R., and Hammen, T. V. D.: Palaeoecology and stratigraphy of the lateglacial type section at Usselo (the Netherlands), Rev. Palaeobot. Palynol., 60, 25-129, https://doi.org/10.1016/0034-6667(89)90072-9, 1989.

Villegas Molina, F.: Laguna de Padul: Evolución geológicohistórica, Estud. Geográficos, 28, 1967, 1967.

Zanchettin, D., Rubino, A., Traverso, P., and Tomasino, M.: Impact of variations in solar activity on hydrological decadal patterns in northern Italy, J. Geophys. Res.-Atmos., 113, D12102, https://doi.org/10.1029/2007JD009157, 2008. 